\title{
Assessing livelihood vulnerability using a Bayesian network: a case study in northern Laos
}

\author{
Victoria Junquera ${ }^{1}$ and Adrienne Grêt-Regamey ${ }^{1}$
}

\begin{abstract}
Agricultural transitions from subsistence to export-oriented production make households more reliant on volatile agricultural commodity markets and can increase households' exposure to crop price and yield shocks. At the same time, subsistence farming is also highly vulnerable to crop failures. In this work, we define household livelihood vulnerability as the probability of falling under an income threshold. We propose the use of a Bayesian network (BN) to calculate the income distribution based on household and community-level variables. BNs reflect relationships of dependence between variables and represent all variables as probability distributions, which allows for the explicit propagation of variability and uncertainty between variables. We focus on two agricultural frontier case study areas (CSAs) in northern Lao PDR that are at different stages in the transition from subsistence to export-oriented agriculture. Because agricultural production is the main livelihood activity in both CSAs, we develop a BN that calculates the probability distribution of net household agricultural production income. BN structure and parameterization are based on data collected in 110 household surveys across both CSAs, as well as interviews with villagers, government officials, and private sector actors. We analyze the effect of crop price and yield variability, land-use portfolio, and land holdings, on the probability of having a negative net agricultural income, which reflects a household's ability to meet its food consumption needs through cash crop sales. Results show that agricultural income is highly sensitive to rubber plantation area, rubber yield, and rubber price given the very large income potential of the crop. Households with larger agricultural areas have a lower probability of falling under an agricultural income threshold regardless of their diversification choices. Households that own more high-value cash crops are more buffered against rice yield shocks despite having higher agricultural income variability. However, low-income households are better off if they maintain a minimum level of rice sufficiency in combination with high-value cash crop production. Diversifying upland cash crops by increasing the share of cardamom (a lowvalue but low-volatility crop) at the expense of rubber (a highly lucrative crop with high price volatility) does not have a sizable beneficial impact, because returns from cardamom are significantly lower than for rubber. We show that BNs can be useful tools for the design and evaluation of rural development policies.
\end{abstract}

Key Words: agricultural frontier; agricultural transition; Bayesian network; diversification; Lao PDR; livelihood vulnerability; price transmission; price volatility; shocks; yield variability

\section{INTRODUCTION}

Subsistence farming, including shifting cultivation, has progressively declined in recent decades with the rise of agricultural commodity production (Pingali 2010, van Vliet et al. 2012). This trend is part of a global social-ecological transformation $^{[1]}$ in rural areas, entailing agricultural expansion and intensification, and often coupled with market integration, urbanization, migration, and regulatory changes (De Koninck 2004). Such agricultural transitions have frequently occurred in agricultural frontiers, as export-oriented intensive agriculture has expanded into regions previously used for subsistence and lowintensity farming (Hirsch 2009, van Vliet et al. 2013, Llopis et al. 2020, Zaehringer et al. 2020).

Transitions from subsistence to market-oriented cash crop production frequently raise farm incomes (de Janvry and Sadoulet 2010, Vang Rasmussen et al. 2018), but wealth distribution issues and the higher costs of inputs can erode income gains (von Braun 1995). Farmers may also face reduced provision of ecosystem services, insecure access to land, displacement, and food insecurity (Wood et al. 2013, Dressler et al. 2017, Heinimann et al. 2017). Such a transition increases households' economic reliance on volatile crop markets and frequently reduces farmlevel diversification (Pingali and Rosegrant 1995, Pingali et al.
2005, Joshi et al. 2007), both of which can reduce resilience to yield and market shocks in agricultural production (Di Falco and Chavas 2008, Lin 2011, de Roest et al. 2018).

Recent agricultural transitions highlight some of the potential negative livelihood impacts of partially or entirely replacing subsistence farming with cash crop production. Vietnamese smallholder farmers who invested in coffee mono-cropping plantations in the 1980s and 1990s underwent significant economic difficulties when coffee prices collapsed in the early 2000s (Meyfroidt et al. 2013). The expansion of maize monocropping in northern Laos created indebtedness among smallholder households, caused soil pollution and erosion, and compromised food sufficiency and security (Ornetsmüller et al. 2018). Cardamom-producing households with low levels of diversification in China and Vietnam were highly vulnerable to harvest failures in 2016 (Rousseau et al. 2019). However, subsistence-based livelihoods are also vulnerable and exposed to exogenous shocks, such as extreme weather events and pests (Morton 2007, Harvey et al. 2014); here, a lack of market access can lead to poverty traps (UNDP 2001, Christiaensen and Subbarao 2005, Barrett 2008). All these issues have raised questions about the effect of agricultural transitions on farmers' livelihood vulnerability.

${ }^{1}$ Planning of Landscape and Urban Systems, ETH Zurich, Zurich, Switzerland 
Table 1. Social-ecological vulnerability components.

\begin{tabular}{|c|c|c|}
\hline \multicolumn{2}{|c|}{ Components of vulnerability and examples } & \multirow{2}{*}{$\begin{array}{l}\text { How components are addressed in the proposed methodology } \\
\text {-Explicit: stressors affecting income streams (e.g., commodity yields and } \\
\text { prices) are included as probability distributions. } \\
\text { • Not included: idiosyncratic stressors, such as health shocks. }\end{array}$} \\
\hline External & $\begin{array}{l}\text {-Exposure to stress, that is, magnitude and frequency of stressors } \\
\text { (Luers et al. 2003) }\end{array}$ & \\
\hline \multirow[t]{8}{*}{ Internal } & $\begin{array}{l}\text {-Ability to cope with stress (Luers et al. 2003) } \\
\text {-Adaptive capacity and learning (Holling 2001, Folke et al. 2002, } \\
\text { Luers et al. 2003, Berkes 2007) }\end{array}$ & $\begin{array}{l}\text { - Not addressed: could be addressed by including coping mechanisms, } \\
\text { such as borrowing, insurance, remittances, or labor wages. } \\
\text {-Not addressed. }\end{array}$ \\
\hline & $\begin{array}{l}\text {-State of the controlling variables relative to a threshold of damage } \\
\text { (Walker et al. 2010) }\end{array}$ & $\begin{array}{l}\text {-Implicit: controlling variables such as soil quality and management } \\
\text { practices are reflected in the probability distribution of crop yields; they } \\
\text { could be explicitly included as variables in the model. }\end{array}$ \\
\hline & $\begin{array}{l}\text {-State of the outcome variable relative to a threshold of damage } \\
\text { (Luers et al. 2003) }\end{array}$ & $\begin{array}{l}\text {-These elements are closely related. They are explicitly addressed: the } \\
\text { outcome variable of the Bayesian network is net household agricultural }\end{array}$ \\
\hline & $\begin{array}{l}\text {-Sensitivity to stress, for example, magnitude of change in well-being } \\
\text { caused by a stressor (Luers et al. 2003), or crop yield variability } \\
\text { given exogenous shocks (Di Falco and Chavas 2008). }\end{array}$ & $\begin{array}{l}\text { production income; its state with respect to a threshold of damage is } \\
\text { given by its probability distribution, which is a joint probability } \\
\text { distribution of all variables affecting the outcome variable. }\end{array}$ \\
\hline & & \\
\hline & expenditures given idiosyncratic and covariate shocks (Günther and & \\
\hline & Harttgen 2009), or crop yield variability given exogenous shocks (Di & \\
\hline & Falco and Chavas 2008). & \\
\hline
\end{tabular}

Livelihood can be defined as a "means to a living" (Chambers and Conway 1992) or, in narrower terms, meeting consumption and economic necessities (Long 1997), whereas vulnerability can be defined as the susceptibility to harm from exposure to stresses and lack of adaptation capacity (Luers et al. 2003, Adger 2006). Thus, livelihood vulnerability expresses the susceptibility, or probability, of losing the means to make a living, and it is a relevant metric of households' long-term well-being (Günther and Harttgen 2009). Livelihood vulnerability has been assessed based on indicators of livelihood needs, capabilities, and access to resources and capitals (Sen 1984, Chambers and Conway 1992, Ribot and Peluso 2003), exposure and sensitivity to hazards or shocks and adaptation capacity (Luers et al. 2003, Adger 2006), or a combination thereof (e.g., Hahn et al. 2009). In development economics, livelihood vulnerability is frequently quantified based on the probability distribution of household consumption (e.g., Christiaensen and Subbarao 2005, Imai et al. 2011), whose variance is determined by the severity and frequency of exogenous shocks and households' coping mechanisms (Kamanou and Morduch 2002, Günther and Harttgen 2009). Instead of household consumption, other measures of well-being can be used, including assets, health status, or income (Cissé and Barrett 2018).

Here, we define household livelihood vulnerability as the probability of falling below an income threshold. We propose the use of a Bayesian network (BN) model to calculate the income distribution and quantify the probability of falling under such a threshold. We demonstrate the implementation of this methodology in two case study areas (CSAs) in northern Lao PDR (Laos) that are at different stages of an agricultural transition and thus represent different stages of agricultural frontier evolution (Pacheco 2012). Because livelihoods in both CSAs are mostly based on agricultural production, and in order to explicitly assess the effect of cash crop production and food sufficiency, we focus specifically on household agricultural production income. We use the $\mathrm{BN}$ to assess the effects of land portfolio, rice sufficiency, and land holdings on net agricultural production income and the likelihood of falling under an income threshold. We further explore the sensitivity of agricultural income to crop price and yield shocks.

In $\mathrm{BNs}$, variables are expressed as probability distributions and linked through directional causal or dependence relations (Kjaerulff and Madsen 2013). This allows for the explicit propagation of variability and uncertainty in the determination of a joint probability distribution (Marcot et al. 2006), which makes BNs useful for addressing different sources of variation (Uusitalo 2007, Stritih et al. 2019). To build and parameterize the $\mathrm{BN}$, we conduct household surveys and interviews with villagers, government authorities and industry stakeholders. To assess the impact of price and yield shocks, we separate the exogenous component from other sources of variability and uncertainty in the data. The use of BNs and joint probability distributions to quantify vulnerability is common in other fields, for example, in engineering (Nielson and DesRoches 2007, Goharian et al. 2018), informatics (Liu and Man 2005), or natural hazards (Maity et al. 2013). To the best of our knowledge, this method has not been applied in the assessment of livelihood vulnerability.

\section{METHODS}

\section{Operationalization of livelihood vulnerability}

Social-ecological vulnerability has external and internal components (Chambers 1989; Table 1), where the external component reflects exposure to stress, that is, the magnitude and frequency of stressors. The internal component reflects the system's sensitivity ${ }^{[2]}$ to stress (the magnitude of change caused by stressors), the system's resilience (its ability to cope with and adapt to stress), and the state of its outcome and controlling variables compared to thresholds of damage (Luers et al. 2003, Walker et al. 2010).

Livelihood vulnerability can be quantified as the probability that a measure of household well-being will fall under a certain 
threshold (Cissé and Barrett 2018). This probability is the area under the probability density curve left of the threshold and is given by the mean, variance (i.e., first and second moments), and shape of the probability distribution. Thus defined, vulnerability increases with increasing variance or decreasing mean (Fig. 1). In skewed distributions, the median income is a more adequate value than the mean (Birdsall and Meyer 2015). A measure of wellbeing frequently used in livelihood vulnerability assessments is household consumption (e.g., Kamanou and Morduch 2002, Christiaensen and Subbarao 2005, Günther and Harttgen 2009). In this work, we propose an alternative measure of vulnerability, namely net household income, which reflects households' income streams, expenses, and ability to save. We thus define livelihood vulnerability as the probability that net household income will fall under a certain threshold.

Fig. 1. Schematic representation of household livelihood vulnerability, defined here as the probability of falling under an income threshold (e.g., zero). This corresponds to the shaded area under the income distribution curve left of the threshold (Fig. A). The diagrams represent income distributions with different mean and standard deviation (sd). For a given sd, vulnerability decreases with increasing mean income (Fig. B) and increases with decreasing mean income (Fig. C). For a given mean income, vulnerability increases with higher income variability (Fig. D).
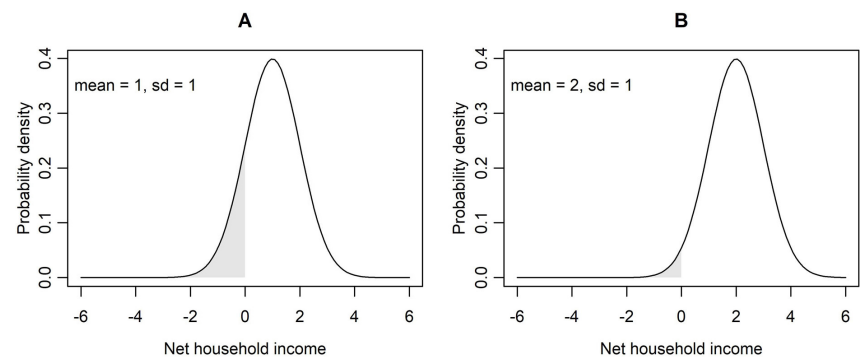

C
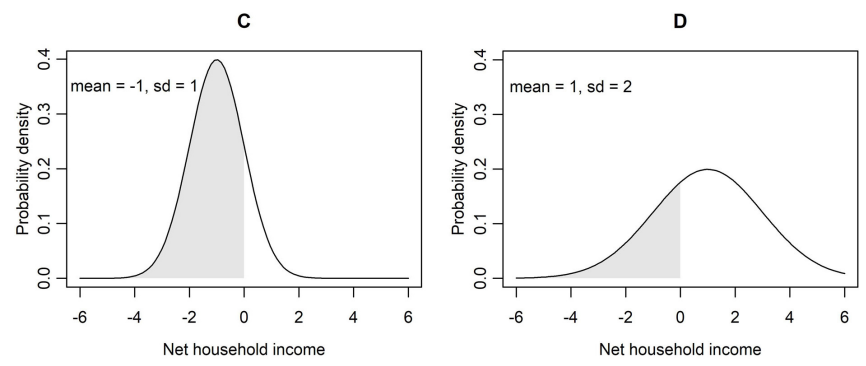

We use zero net income as the threshold, reflecting a situation in which a household is forced to borrow or sell assets. This threshold also allows for comparability between different regions. However, the probabilistic representation of income makes it possible to evaluate the probability of falling under any threshold. Alternative thresholds could be selected to better reflect local poverty levels, such as a purchasing power parity (PPP) index (Banerjee and Duflo 2007) or a multidimensional poverty index (MPI; Alkire and Santos 2014).

We propose the use of a $\mathrm{BN}$ model to estimate the income distribution. Because BNs propagate uncertainty and variability between linked variables, the resulting income distribution reflects the variability of all the parameters included in the model, such as yield and price variability, or between-household variability. This operationalization of livelihood vulnerability directly or indirectly addresses several components of social-ecological vulnerability (Table 1). By representing income streams and associated parameters (e.g., crop prices and yields) as probability distributions, the $\mathrm{BN}$ model explicitly addresses the frequency and intensity of stressors. The sensitivity of the outcome variable (e.g., net household income) to stressors is implicit in the parameterization of the model and can be explicitly evaluated by conducting sensitivity analyses. The state of the outcome variable relative to a threshold of damage is explicitly modeled. Controlling variables, such as soil quality, are implicitly addressed by reflecting their impact on other variables, such as yields; alternatively, they can be explicitly added to the BN. This approach does not, however, address a number of important elements of social-ecological vulnerability, such as adaptation capacity or learning.

Because agriculture is the main livelihood activity in the CSAs under analysis, and our focus is on the impact of agricultural transitions, we restrict the analysis to net agricultural production income, including income from cash crop sales and net purchase of rice for household consumption. The threshold, zero net agricultural production income, reflects the likelihood that a household will not be able to meet its rice consumption needs through cash crop sales.

We thus make a distinction between our definition of household livelihood vulnerability in terms of net household income, as shown in Figure 1, and the methodological implementation in this paper, limited to net agricultural production income. The BN model developed herein does not address other important household income streams and expenses that would be necessary for a full quantification of livelihood vulnerability, such as wages, household expenses other than rice (e.g., fertilizer cost, other food items, clothing, schooling), or expenses associated with idiosyncratic shocks (e.g., health shocks). It also does not address coping mechanisms, such as borrowing, remittances, insurance, or asset sales (Fig. 2), or broader aspects of vulnerability beyond income.

\section{Case study areas and data collection}

The two CSAs, Oudomsin and Prang ${ }^{[3]}$, are located in northern Laos's Luang Namtha Province, bordering on southern China's Xishuangbanna Prefecture in Yunnan Province (Fig. A1.1). Prior to the large-scale production of export crops, households relied on growing paddy rice in lowland irrigated fields and traditional upland rice (also known as shifting cultivation, swidden, or slashand-burn) in higher altitude and sloping upland plots; farmers also sold excess rice, cotton, and other crops in local markets. Both areas were still largely rice self-sufficient in 2017 (Table A1.1), although with significant between-household variability.

The Oudomsin CSA (population in $2005=2950^{[4]}$ ) is located in Sing District, roughly three kilometers from the Chinese border and along the highway that leads to Mengla (Muang La) District in China. Export crop production started in the 1990s with sugarcane. Rubber plantations started around 2003 and expanded rapidly between 2004 and 2008. Around 2013-2017, numerous households leased their rice paddies to Chinese investors for 
Fig. 2. Schematic of the Bayesian network model indicating variable type and parameterization method. Each box represents a variable in the model, implemented as a discretized probability distribution. Alternatively, variables can be "instantiated" (fixed) to a certain value. $\mathrm{CHN}=$ China, $\mathrm{LNT}=$ Luang Namtha Province.

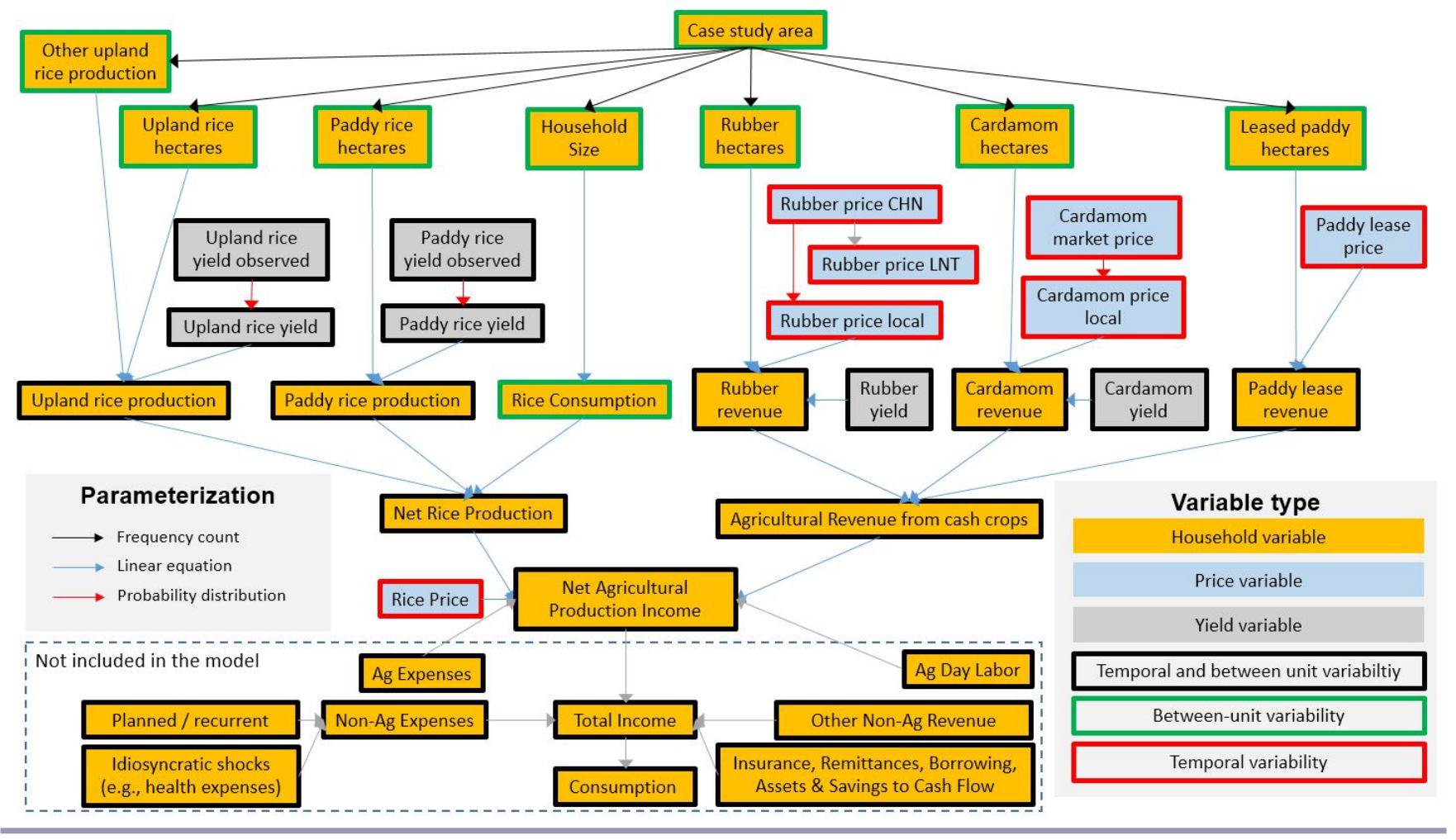

banana plantations (Friis and Nielsen 2016, 2017), which mostly disappeared by the end of 2017 because of pests and other factors and were mostly replaced by sugarcane plantations. Sugarcane plantations are either managed by the household or, frequently, leased out to other villagers ${ }^{[5]}$. Traditional upland rice production has been abandoned, except in newly converted rubber plots, where rice is intercropped up to three years. Mean annual household income in 2017 is US\$3900 (range: $0-U S \$ 15,000$ ), $85 \%$ of which is agricultural income, including revenue from cash crop sales $(57 \%)$, cattle sales $(2 \%)$, and agricultural day labor wages $(26 \%)$. Nonagricultural income in both areas comes mostly from handicraft sales, construction work, or convenience store ownership ${ }^{[6]}$. During the data collection periods, income from remittances was almost negligible in both CSAs. The average farm size is 5.6 ha, comprising 4 (range: $1-12$ ) ha of rubber, $0.6(0-2)$ ha of rice paddy, and $0.9(0-4)$ ha of paddy land converted to a cash crop. The average value of household livestock, mostly buffalo and pigs, is US\$760.

The Prang CSA (population in $2005=1250^{[7]}$ ) is located approximately 60 kilometers from the Boten border to China along the highway that links Bangkok, Thailand to Kunming, China. Development organizations and investors introduced upland cash crops starting in the mid-2000s, especially rubber and cardamom (Amomum spp.). Many Prang households still practice upland rice cultivation because of the limited availability of paddy land, and upland areas are still dominated by shifting cultivation fallows (Junquera et al. 2020). Unlike Oudomsin households,
Prang households have not converted rice paddies to cash crop plantations, but paddy hectares per person are roughly the same as in Oudomsin because the latter had more paddy prior to its partial conversion to cash crop plantations (Table A1.1). Prang households have fewer upland cash crop hectares than Oudomsin and a more diversified income based on cattle, cardamom, and rubber. Mean annual household income in 2017 is US\$1100 (range: US\$0-4500), 95\% of which is agricultural income, including revenue from cash crop sales $(72 \%)$, cattle sales $(16 \%)$, and agricultural day labor wages $(7 \%)$. The average farm size is 2.9 ha, comprising $1.1(0-3)$ ha of rubber, $0.4(0-2)$ ha of cardamom, and $0.5(0-1)$ ha of rice paddy. The average value of household livestock, mostly cows and pigs, is US\$1500.

A total of 110 household surveys were conducted from October to December 2016 and November to January 2017. Ten households were randomly selected within the six villages selected in the Oudomsin CSA $(\mathrm{N}=60)^{[8]}$, and in all five villages located in the Prang CSA $(\mathrm{N}=50)^{[9]}$. The survey asked for information on household socioeconomic conditions in December 2017, including the number of persons and labor; age and education of the head of the household; agricultural and total income; rice production; and number of buffalo, cows, and pigs. The survey also elicited plot-level information for household agricultural plots $(n=621)$, including size, location, distance from the village, slope, land-use history (year of adoption and type of land use since the plot was opened or acquired), yield, and cash crop prices for the current year (farm gate price) and the year the cash crop 
was first planted (reflecting price knowledge at the time of planting). Yield range data, representing the minimum and maximum yield values witnessed by the farmer since 2000 or since the crop was first planted, were elicited for 47 paddy rice plots (out of 107) and four upland rice plots (out of 27). Focus groups were carried out in each village to understand village history and land use trajectory. Interviews were carried out with three rubber companies, one cardamom investor, and with district and province authorities.

\section{Bayesian network model of household vulnerability}

BNs are probabilistic models whose variables are linked in a noncircular (acyclic) network through relations of dependence. The information content of each variable is represented as a probability distribution. The conditional probability distribution of a variable is calculated based on (i.e., conditional on) the probability distribution of its "parent" (incoming) variables based on Bayes' theorem, which links the probability of event $A$ conditional on event $\mathrm{B}$ as $\mathrm{P}(\mathrm{A} \mid \mathrm{B})=\mathrm{P}(\mathrm{B} \mid \mathrm{A}) \times \mathrm{P}(\mathrm{A}) / \mathrm{P}(\mathrm{B})$. If a variable has no parents and hence is not dependent on any other variable in the model, it is parameterized using an independent probability distribution (Uusitalo 2007, Kjaerulff and Madsen 2013). The joint probability distribution over the set of variables $\mathrm{X}_{1}, \mathrm{X}_{2}, \ldots \mathrm{X}_{\mathrm{n}}$ in the $\mathrm{BN}$ can be expressed as

$$
P(X)=P\left(X_{1}, X_{2}, \ldots X_{n}\right)=\prod_{i=1}^{n} P\left(X_{i} \mid X_{p a(i)}\right)
$$

where $\mathrm{X}_{\mathrm{pa}(\mathrm{i})}$ are the parent variables of $\mathrm{X}_{\mathrm{i}}$. In other words, the joint probability distribution of a $\mathrm{BN}$ depends on the probability distribution of all variables in the model, but the probability distribution of each variable is calculated based only on its parents' probability distribution, or as an independent probability distribution for parent-less variables (Kjaerulff and Madsen 2013). If the state of a variable is known, the information content of that variable can be set to a specific value (i.e., fixed or "instantiated"), rather than specifying the variable as a probability distribution. In $\mathrm{BNs}$, information is propagated forward and backward when the information content of a variable is updated or instantiated (Fig. A1.3).

The BN is implemented using the software Netica ${ }^{\mathrm{TM}}$ Version 5.24, which includes a graphical interface and built-in algorithms for Bayesian inference. Netica calculates discretized probability distributions, that is, density histograms. The histogram for the output node is imported into the $\mathrm{R}$ statistical language and environment ( $\mathrm{R}$ Core Team 2019) to estimate its quantiles using the function ApproxQuantile in the HistogramTools package (Stokely 2015). All statistical and regression analyses are conducted using $\mathrm{R}$.

\section{BN structure}

The outcome variable of the $\mathrm{BN}$ is net household agricultural production income, including revenues from cash crop sales and paddy land leases, and revenues or expenses from net household rice production. It excludes labor wages and household expenses other than those from rice (Fig. 2; Fig. A1.2). Net household rice production is equal to rice production minus consumption, which is calculated as a function of household size. Cash crop revenue includes revenue from sales of rubber and cardamom, which depends on plot size, crop yield, and crop price, as well as income from cash crop production on paddy land (referred to as "paddy lease," whether it is leased or managed by the household), which depends on plot size and lease price. Rice production includes paddy rice, upland rice, and "other" upland rice intercropped with rubber. Paddy and upland rice production depend on agricultural area and yield. Paddy and upland rice yields are separated into observed yields, elicited in the survey, and actual yield variability, which excludes measurement error (e.g., error stemming from inaccurately reported plot sizes in the survey). Crop prices are broken down into local prices paid or received by the household and market prices in commodity exchanges.

\section{Variable discretization}

BNs can only deal with continuous variables in a limited manner (Kjaerulff and Madsen 2013), and their implementation requires the discretization of variables into intervals or states. However, variable discretization captures only rough characteristics of the original distribution (Uusitalo 2007). We discretize each node with the aim of reflecting the original distribution as best as possible by maximizing the number of states while minimizing the number of states with a low frequency count.

\section{Sources of variability and uncertainty}

Variability represents the diversity or heterogeneity of a population across space or time. Uncertainty, including measurement error, is a measure of the state of information about the true value of a variable (Anderson and Hattis 1999, Begg et al. 2014). To reflect the impact of price and yield variability on livelihood vulnerability, it is necessary to isolate exogenous yield and price shocks from other sources of variability and uncertainty, both of which contribute to the variability of the data.

Sources of variability in the data include exogenous shocks, household and spatial heterogeneity within the CSA, seasonal variability, buyer heterogeneity, and crop age. Exogenous shocks can be covariate (affecting the entire community), idiosyncratic (household or unit-specific), or frequently both (Günther and Harttgen 2009). We distinguish between variables with temporal variability (e.g., crop prices), between-unit or cross-sectional variability (e.g., household variables), or both (e.g., crop yields, which change over time and between agricultural plots; Fig. 2). Sources of uncertainty include measurement error, in particular associated with inaccurate reporting of plot sizes. Table 2 shows how variability and uncertainty are addressed for each variable.

\section{$B N$ parameterization}

Variables are parameterized using (i) frequency counts as approximations of their probability distributions (Luers et al. 2003), (ii) deterministic equations as a function of the parent variable(s), or (iii) a probability distribution as a function of the parent variable(s; Netica 2019). Variables that show no statistically significant difference between the CSAs (crop yields and prices) are parameterized identically for both study areas. Table A1.2 explain how each variable is parameterized.

Rubber price: Rubber prices offered by buyers or traders to the farmers in the CSAs are influenced by the rubber market price in China, which is transmitted daily through the value chain ${ }^{[10]}$. The Luang Namtha Province Investment and Commerce Office (PICO) monitors rubber market price on the web site of a Chinese rubber company and calculates suggested rubber prices using a conversion ("pegging") factor of 0.42 (Vongvisouk and Dwyer 
Table 2. Sources of variability and uncertainty in the data and how they are addressed in the Bayesian network (BN).

\begin{tabular}{|c|c|c|c|}
\hline Variable type & Sources of variability and uncertainty in the data & Type of variability & How it is addressed in $\mathrm{BN}$ model \\
\hline \multirow[t]{5}{*}{$\begin{array}{l}\text { Crop prices (rubber, } \\
\text { cardamom, rice) }\end{array}$} & Price fluctuations in international markets & Temporal & $\begin{array}{l}\text { Explicit nodes for market price reflecting variability over } \\
\text { time. }\end{array}$ \\
\hline & Differences in price between local buyers & Between-household & Standard deviation of cross-sectional local price in 2017. \\
\hline & Season & Between-household & $\begin{array}{l}\text { Eliminated or reduced by using annual smoothing or } \\
\text { averages. }\end{array}$ \\
\hline & Quality/variety (applies especially to rice) & Between-household & $\begin{array}{l}\text { Partially addressed: Used only hulled rice for consistency; } \\
\text { difference between sticky and boiled rice not addressed } \\
\text { and reflected in data variability. }\end{array}$ \\
\hline & Measurement error & Between-household & $\begin{array}{l}\text { Eliminated or reduced by using annual smoothing or } \\
\text { averages. }\end{array}$ \\
\hline \multirow[t]{4}{*}{ Paddy lease price } & Price fluctuations in international markets & Temporal & $\begin{array}{l}\text { The temporal variability of the sugarcane and banana } \\
\text { markets is not reflected, but the long-term collapse of the } \\
\text { banana market (and replacement by sugarcane) is } \\
\text { reflected. }\end{array}$ \\
\hline & $\begin{array}{l}\text { Spatial variability of biophysical characteristics. } \\
\text { Possible spatial correlation between plots. }\end{array}$ & Between-plot & $\begin{array}{l}\text { Not eliminated and thus reflected in the variance of the } \\
\text { probability distribution. }\end{array}$ \\
\hline & Differences in contract negotiation & Between-plot & $\begin{array}{l}\text { Not eliminated, and thus included in the variance of the } \\
\text { probability distribution. }\end{array}$ \\
\hline & Measurement error & Between-plot & $\begin{array}{l}\text { Not eliminated, and thus included in the variance of the } \\
\text { probability distribution. }\end{array}$ \\
\hline \multirow[t]{6}{*}{$\begin{array}{l}\text { Crop yields (rubber, } \\
\text { cardamom, rice) }\end{array}$} & $\begin{array}{l}\text { Spatial biophysical heterogeneity. Possible spatial } \\
\text { correlation between plots. }\end{array}$ & $\begin{array}{l}\text { Between-plot; } \\
\text { temporal }\end{array}$ & $\begin{array}{l}\text { Rubber, cardamom: included in the variance of the } \\
\text { probability distribution. } \\
\text { Rice: eliminated by using yield range reflecting plot- } \\
\text { specific temporal variability. }\end{array}$ \\
\hline & $\begin{array}{l}\text { Household-specific management practices. Possible } \\
\text { spatial correlation between plots. }\end{array}$ & Between-household & $\begin{array}{l}\text { Rubber, cardamom: included in the variance of the } \\
\text { probability distribution. } \\
\text { Rice: eliminated by using yield range reflecting plot- } \\
\text { specific temporal variability. }\end{array}$ \\
\hline & Covariate shocks (e.g., a weather event) & Temporal & $\begin{array}{l}\text { Rubber, cardamom: included in the variance of the } \\
\text { probability distribution. } \\
\text { Rice: Reflected in yield range; hence, not eliminated, and } \\
\text { thus included in the variance of the probability } \\
\text { distribution. }\end{array}$ \\
\hline & $\begin{array}{l}\text { Idiosyncratic shocks (e.g., a pest attacking a plot). } \\
\text { Possible spatial correlation if several plots are } \\
\text { affected. }\end{array}$ & $\begin{array}{l}\text { Temporal; Between- } \\
\text { plot }\end{array}$ & $\begin{array}{l}\text { Rubber, cardamom: included in the variance of the } \\
\text { probability distribution. } \\
\text { Rice: reflected in yield range; hence, not eliminated, and } \\
\text { thus included in the variance of the probability } \\
\text { distribution. }\end{array}$ \\
\hline & Age of the crop (rubber and cardamom) & Temporal & Addressed by using only data for mature crops. \\
\hline & $\begin{array}{l}\text { Measurement error; rice paddy yields are especially } \\
\text { affected by inaccurate reporting of plot size, which } \\
\text { is generally small. }\end{array}$ & Between-household & $\begin{array}{l}\text { Rubber, cardamom: included in the variance of the } \\
\text { probability distribution. } \\
\text { Rice: largely eliminated by using yield range. }\end{array}$ \\
\hline $\begin{array}{l}\text { Household } \\
\text { variables (size, }\end{array}$ & Household differences & Between-household & $\begin{array}{l}\text { Not eliminated, and thus included in the variance of the } \\
\text { probability distribution. }\end{array}$ \\
\hline $\begin{array}{l}\text { hectares of rice and } \\
\text { cash crops, rice } \\
\text { consumption) }\end{array}$ & Measurement error & Between-household & $\begin{array}{l}\text { Not eliminated, and thus included in the variance of the } \\
\text { probability distribution. }\end{array}$ \\
\hline
\end{tabular}

2017:13). This factor partly represents a correction for moisture in the latex, transport, storage, and preprocessing costs (Vongvisouk and Dwyer 2017).

Because PICO prices are suggested and reflect, rather than affect, local rubber prices, these two prices are not linked in the BN. Instead, the local rubber price is tied to the rubber market price in China. We use annual average rubber futures prices from the Singapore Commodities Exchange (SCE) from 1995 to 2017 (Indexmundi 2020) as a proxy for rubber prices in China because they are very similar to rubber prices at the Shanghai Commodities Exchange between 2014 and 2018 (Quandl 2019; Fig. 3A).

Given a rubber market price in China, we assume that local rubber prices are normally distributed. In the $\mathrm{BN}$, the local rubber price is parameterized using a normal distribution with mean equal to the rubber market price in China multiplied by 0.42 , and standard deviation (SD) equal to the SD of 2017 local rubber prices elicited in the household survey (Fig. 3B). We assume that this SD, associated with seasonal changes, mode of transport, buyer, and other factors, is representative of CSA-level price variability in any year. Thus, the variability of local rubber price in the $\mathrm{BN}$ reflects the cross-sectional local price variability in a given year, as well as the variability of international rubber market prices over an 18-year period.

The coefficient of 0.42 is the regression coefficient of an Ordinary Least Squares (OLS) regression with PICO prices as the dependent variable and SCE prices as the independent variable $\left(\mathrm{SD}=0.03 ; \mathrm{p}\right.$-value $\left.<0.001 ; \mathrm{R}_{\mathrm{adj}}=0.92\right)$. An alternative would 
Fig. 3. (A) Rubber prices from different sources: Singapore Commodity Exchange Asia Rubber grade RSS3 (Indexmundi 2020), Shanghai Commodity Exchange (Quandl 2019), Luang Namtha Province Investment and Commerce Office (Vongvisouk and Dwyer 2017), and recall rubber prices elicited in the survey, as well as their smoothed values. CNY = Chinese Yuan. (B) Illustration of rubber price parameterization in the Bayesian network $(\mathrm{BN})$ : for market price in China (Price_R_CHN), using a frequency count of annual average values; for local price (Price_R), assuming a normal distribution conditional on Price_R_CHN, with mean equal to Price_R_CHN times a conversion factor, and standard deviation (SD) equal to the standard deviation of 2017 local (survey recall) prices.

\section{A}

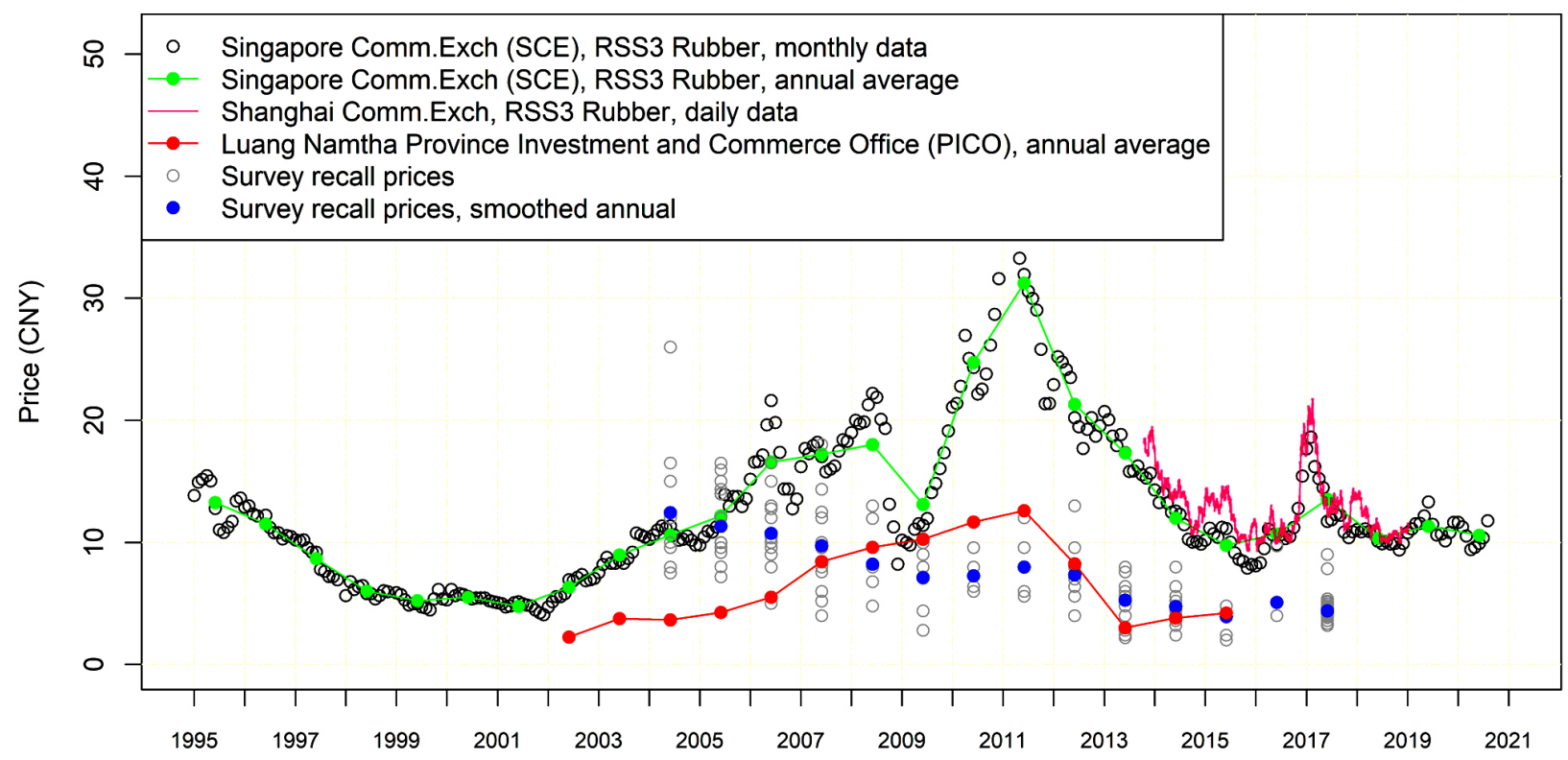

B

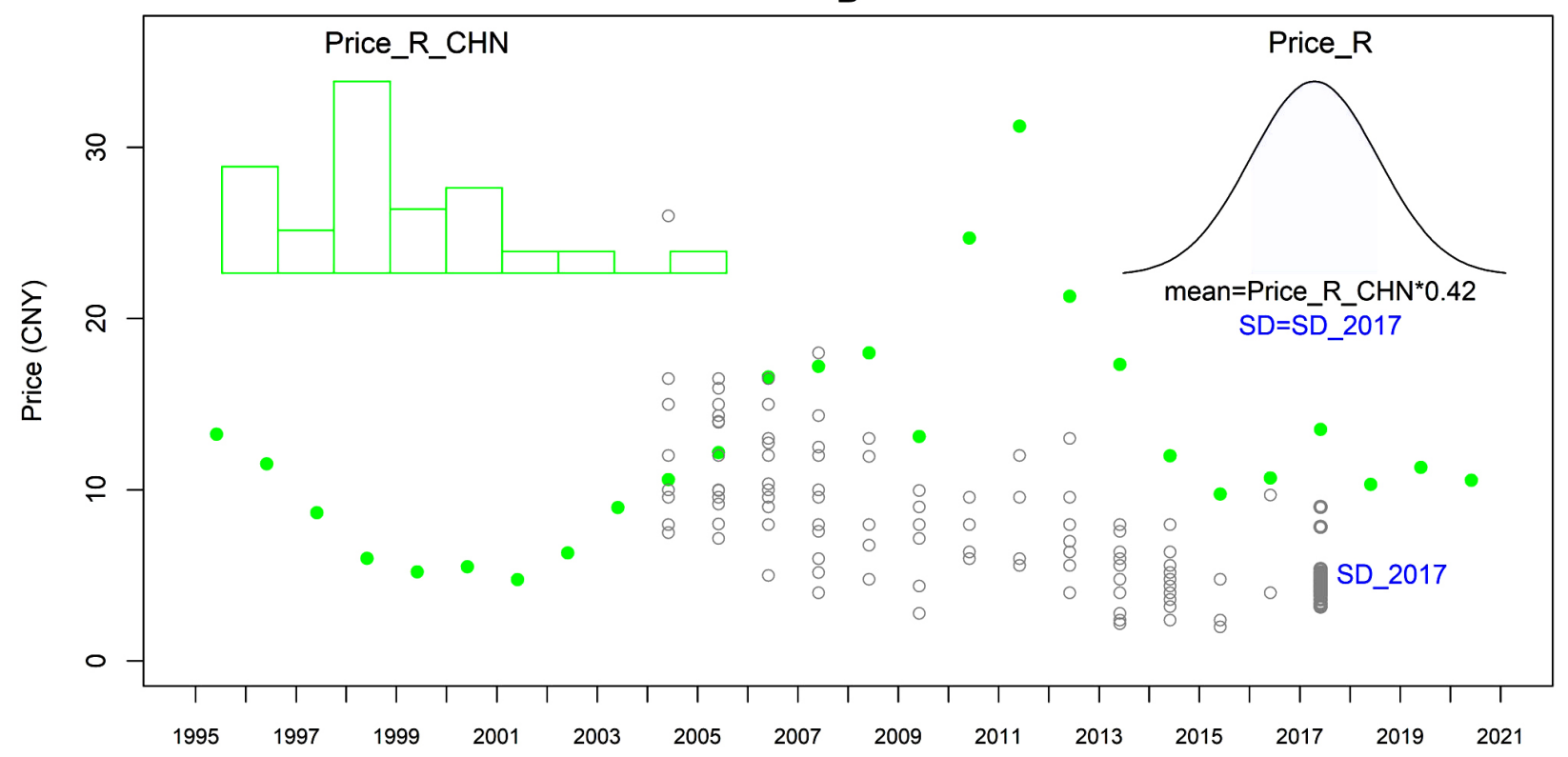


be to use OLS regression with detrended rubber prices to account for possible autocorrelation and nonstationarity in the data (Podobnik and Stanley 2008), which yields a coefficient of 0.46 $\left(\mathrm{SD}=0.09 ; \mathrm{p}\right.$-value $\left.<0.001 ; \mathrm{R}_{\mathrm{adj}}=0.65\right)$. However, because we reflect actual, and not detrended prices, in the $\mathrm{BN}$, and the regression coefficient of 0.42 coincides with the pegging factor cited in the literature, we use this value.

Cardamom price: The local price of cardamom is parameterized using a similar approach as for rubber. However, we do not have international cardamom market price data. We assume that the temporal variability of international market prices can be approximated by the temporal variability of local annually averaged prices. The market price is parameterized using a frequency count of smoothed annual cardamom price data elicited in the survey, covering the period 2008-2017. We use smoothed values instead of annual averages because we have few values for some years (e.g., $\mathrm{n}=2$ in 2017). The smoothed values are calculated using smoothing splines with degrees of freedom $\mathrm{df}=7$ (for 10 years in the time series). The local cardamom price is parameterized using a normal distribution with mean equal to its market price and standard deviation equal to the SD of 2017 cardamom prices elicited in the survey.

Rice price: The price of rice is parameterized using a similar approach as for rubber. To reflect rice market price, we use a frequency count of annual producer price indices for paddy rice [11] for 2000-2016 (FAOSTAT 2020). We assume that price variability is identical for upland and paddy rice, as reported market prices generally do not distinguish between upland and paddy rice, but rather between glutinous and nonglutinous rice (e.g., Loening 2011, Nolan 2016). The local price of rice is parameterized using a normal distribution with mean equal to its market price multiplied by a conversion factor; the standard deviation is equal to the SD of 2017 rice price data elicited in the household survey. As conversion factor we use 1.46e-3, the ratio of mean local price in 2017 to the FAOSTAT price index in 2016, which we assume is a reasonable approximation for the price index in 2017, because our data show that local rice prices did not change perceivably between the two years. To ensure consistency, only unhulled (i.e., with hull) rice prices are used in the calculation of local prices, because the majority ( $86 \%$ by household) of rice sold is unhulled. No statistically significant difference (t-test p-value $=0.16$ ) was found between unhulled rice sold (mean $=0.30 \mathrm{US} \$ /$ $\mathrm{kg}, \mathrm{SD}=0.02$ ) and unhulled rice purchased (mean $=0.33 \mathrm{US} \$ /$ $\mathrm{kg}, \mathrm{SD}=0.06)$. Hence, in the $\mathrm{BN}$ rice price is parameterized identically for sales and purchase price. Eight of 15 households that purchased rice on the market bought hulled (i.e., white) rice. Although the hull only makes up $20 \%$ by weight (Andreevska and Simeonovska 2012), hulled rice was roughly twice as expensive (mean $=0.68 \mathrm{US \$} / \mathrm{kg}, \mathrm{SD}=0.06)$ as unhulled rice, reflecting not only the hulling process, but also more expensive varieties. In fact, households that purchase hulled rice generally have higher incomes. Thus, the $\mathrm{BN}$ reflects conservative rice prices.

Paddy lease price: The paddy lease price represents income from paddy land converted to banana or sugarcane plantations, which are generally leased out, and in some instances managed by the household. The paddy lease price is parameterized using frequency counts of revenue per hectare for each leased paddy since it was first leased out, including the years when no income was generated after banana investors left unannounced and households did not have the time to convert to another crop within less than one year. The variable has a trimodal distribution with peaks at zero (reflecting periods of no income), at around 500 US\$ per hectare (approximate return to land in sugarcane plots in the year 2017) and around 2000 US\$ per hectare (approximate return to land from banana leases during the banana boom from 2013-2016).

Rubber and cardamom yield: The yields of rubber and cardamom are parameterized using frequency counts of 2017 yield data in plots with mature trees (10 years or older for rubber and three years or older for cardamom). Villagers reported that cardamom yields are relatively predictable and decline throughout the three productive years of the six-year life span of the plant; crosssectional cardamom yield data include mature plants of all ages and thus reflect this temporal trend. Rubber trees take seven years to mature, and the yield is very low for the first three years, peaking around year 20, and ending around year 30 to 35 (Manivong and Cramb 2008). Because we use rubber yield values of trees in the third or higher year of production, and rubber trees were planted after 2003 in Oudomsin and 2006 in Prang, the range of productive tree age is only five years (2013-2017) in Oudomsin and two years (2016-2017) in Prang; thus, the data provide a limited representation of long-term rubber yield variability. Rubber and cardamom yield variability includes (i) measurement error, which is expected to be small, (ii) between-plot and betweenhousehold variability, and (iii) temporal variability.

Rice yields: Paddy rice and upland rice yields elicited in the survey have a relatively large uncertainty associated with inaccuracies in reported plot sizes, especially for paddy plots, which are small, averaging $0.8( \pm 0.4)$ ha in Oudomsin and $0.3( \pm 0.2)$ ha in Prang. We wish to obtain the true yield variability of the crops not including measurement error and between-household variability. To this end, we use plot-level yield range values, obtained for a subset of paddy and upland rice plots. The yield range (highest value minus lowest value) is used to obtain a rough estimate of the theoretical standard deviation (SD) of the plot-level yield variability using the formula $\mathrm{SD} \approx$ yield_range/4 (Hozo et al. 2005). We then average the SD values across paddy and upland plots, arriving at $\mathrm{SD}_{\text {yield_paddy }}=0.33$ and $\mathrm{SD}_{\text {yield_upland_rice }}=0.22$. Paddy rice yield is parameterized assuming a normal distribution with mean equal to the average of observed yield values in both CSAs and the SD given above; the same methodology is applied to upland rice yield. Although agricultural yields tend to exhibit negative skewness (Chang and Chen 2005, Upadhyay and Smith 2005, Hennessy 2009), a normal distribution can be considered a reasonable approximation (Just and Weninger 1999). Observed yield variables are parameterized using frequency counts of plotlevel yield data.

Household variables: Agricultural plot size and household size are parameterized for each CSA using frequency counts of 2017 data from the survey. The relationship between rice consumption and number of persons in the household is estimated using an OLS regression with an intercept (adjusted $\mathrm{R}^{2}=0.17$; coefficient $=0.18 \pm 0.04 ;$ intercept $=1.11 \pm 0.26 ; \mathrm{p}$-value $=<0.001)$. Although the model explains only $17 \%$ of the variance, alternative models including higher order terms or other variables, such as household number of children and CSA fixed effects, do not 
improve the fit, and the additional variables are not significant. Household rice consumption is parameterized as a function (equation) of household size using the OLS slope and intercept estimates.

\section{Sensitivity analysis}

The sensitivity of a variable with respect to other variables in a $\mathrm{BN}$ can be measured using variance reduction, entropy reduction, or scenario analysis (Marcot 2012). To determine the sensitivity of agricultural production income to other variables in the $\mathrm{BN}$, we use variance reduction, calculated as the percent reduction in variation of a variable when the value of another variable is fixed (Marcot 2012). In addition, we run scenarios with low and high values of rubber price and rice yield to show the impact of these variables on net agricultural production income.

\section{Household-level BN and scenario analysis}

The model presented above (Fig. 2) yields the theoretical probability distribution of net household agricultural production income at the level of the CSA. It includes all sources of CSAlevel spatial and temporal variability, including household heterogeneity. The area under the probability distribution left of the threshold can be interpreted as the fraction of households in the CSA falling under the threshold, or alternatively as the probability that a household will fall under the threshold. The model is parameterized based on past observations and its output can be assumed to reflect current and near-future conditions (Günther and Harttgen 2009).

The calculated theoretical distribution is different from the empirical distribution measured in the CSAs in 2017, which only reflects between-household variability. The theoretical variability is larger than the empirical variability because it reflects betweenhousehold variability and temporal variability of parameters affecting income, such as prices and yields.

By fixing (instantiating) certain variables, the model can be used for scenario analysis. For instance, fixing household variables yields the income distribution for specific household types. We construct household-level BNs for an average low-income household and an average high-income household in each CSA, defined as those falling under the 25th agricultural income percentile or above the 75th percentile, respectively (Table A1.3A). We calculate average household variables (number of persons and crop hectares) for each income group (Table A1.3-B) and instantiate the respective nodes in the $\mathrm{BN}$.

To analyze the impacts of crop diversification, we define two additional household types that are applicable to both CSAs: a low-income household (corresponding to a low-income household in Oudomsin or a low to middle-income household in Prang), and a middle-income household (corresponding to a middle-income household in Oudomsin or a middle to upperincome household in Prang). The middle-income household has six persons, four hectares of upland crops, which can be planted with rubber and/or cardamom, and 1.5 hectares of paddy land, which can be planted with rice or leased out for cash crop production (paddy lease). The low-income household has five persons, two hectares of upland crops and 0.4 hectares of paddy land, with similar diversification choices. In addition to cardamom and rubber, the low-income household can also produce upland rice in upland fields to supplement its paddy rice production (Table A1.3-C). Finally, fixing rubber prices, we assess the effect of low- and high-price scenarios on these two household types.

\section{RESULTS}

\section{Case study area comparison}

Oudomsin households have a higher theoretical net agricultural production income and income variability than Prang households (Fig. 4A). The higher median income in Oudomsin is explained by the much higher returns from rubber compared to cardamom, and the slightly higher returns from paddy leases compared to paddy rice production (Table A1.1). The long positive tail end in Oudomsin indicates a high probability of above-average income in a given year, caused by the large income potential from rubber. Despite their lower income variability, Prang households have a higher probability of having a negative net agricultural production income than Oudomsin households, i.e., they are less likely to meet their rice consumption needs through cash crop sales.

Figure 4A also shows the median net agricultural production income in 2017 in each CSA (empirical median), and the theoretical median calculated from the BN output node. The fact that the empirical median is lower than the theoretical median shows that both CSAs were undergoing a period of below-average income in 2017 , caused by low rubber prices and a low return on paddy leases after the abandonment of banana plantations.

High-income households have larger land holdings and more land dedicated to cash crop plantations in both areas (Table A1.3), which translates into higher median incomes (Fig. 4B \& C). Despite the fact that agricultural income variability is larger for high-income households, the probability of having negative net income is at least an order of magnitude lower than for lowincome households. In other words, high-income households not only have higher incomes, but they also have a lower probability of not being able to meet their rice consumption needs, compared to low-income households. Results also show that income inequality, reflected by the difference in income distributions between low- and high-income households, is smaller in Prang than in Oudomsin (Fig. 4B \& C).

A striking result is that the probability of having negative net agricultural production income is not substantially lower for lowincome households (Fig. 4B) compared to the totality of households in each CSA (Fig. 4A), despite the lower theoretical median income of low-income households. This is probably explained by the fact that all households, including low-income households, are largely rice self-sufficient in both CSAs (Table A1.3), i.e., they are not dependent on cash crop income to cover their rice consumption needs.

\section{Impact of rubber price and rice yield}

Results of the sensitivity analysis show that over $80 \%$ of the theoretical variability in agricultural production income is attributable to household rubber hectares, rubber yield, and rubber price (Fig. A4). Agricultural production income is significantly less sensitive to other variables, such as paddy lease income (Oudomsin only) and household rice production. Cardamom has a negligible impact on household income variability, even though cardamom income composes almost half 
Fig. 4. Probability distribution of net household agricultural production income in each case study area (output from the Bayesian network [BN] model) for (A) for all households, (B) an average low-income household, and (C) an average high-income household in Oudomsin (oud) and Prang (pra). The dashed lines indicate the modeled (theoretical) median of the distribution (m_th), and the solid lines indicate the empirical median of 2017 (m_emp). Smoothing curves are added to the discretized probability distribution outputted by the BN model. The theoretical probability of falling under zero net agricultural production income $(\mathrm{P}<0)$ is indicated.

\section{(A) All households}

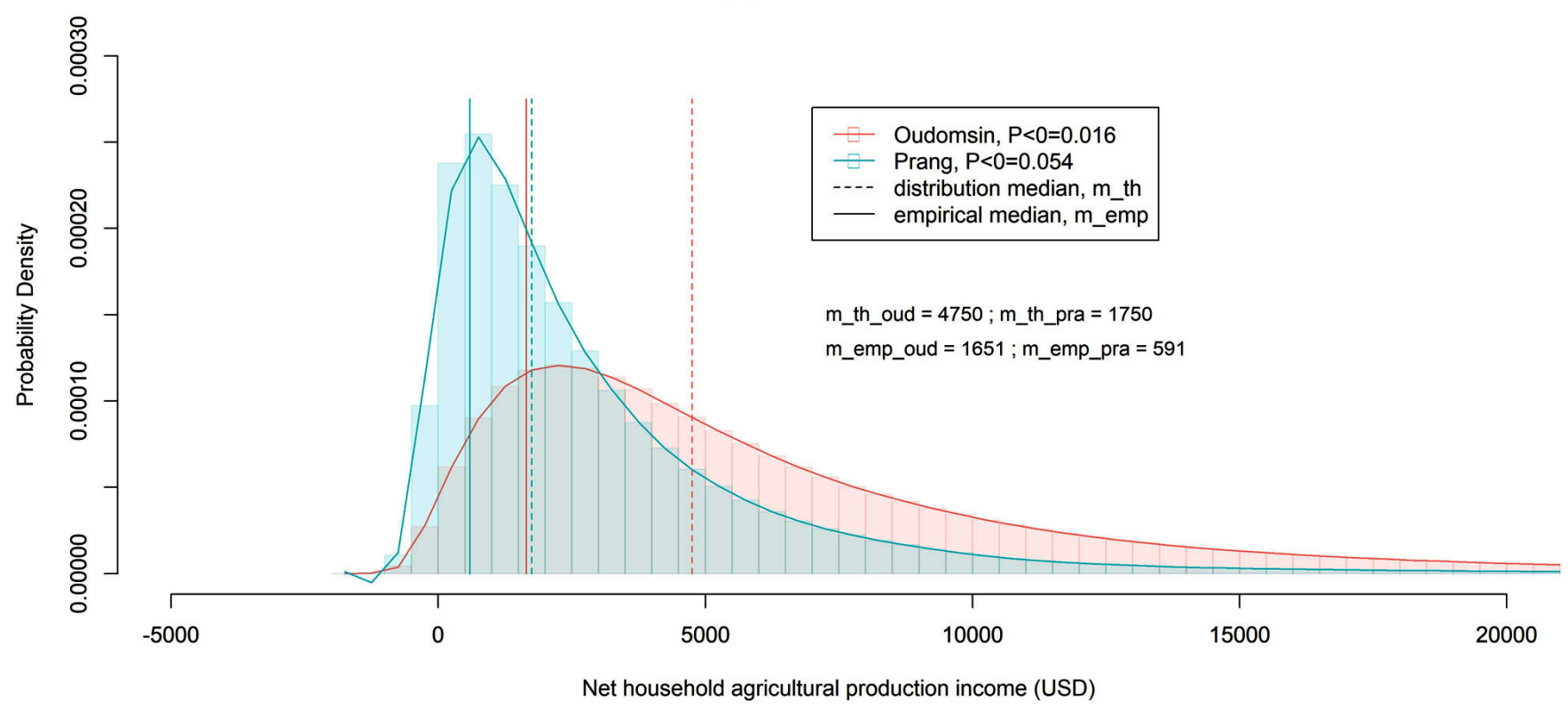

(B) Low-income household

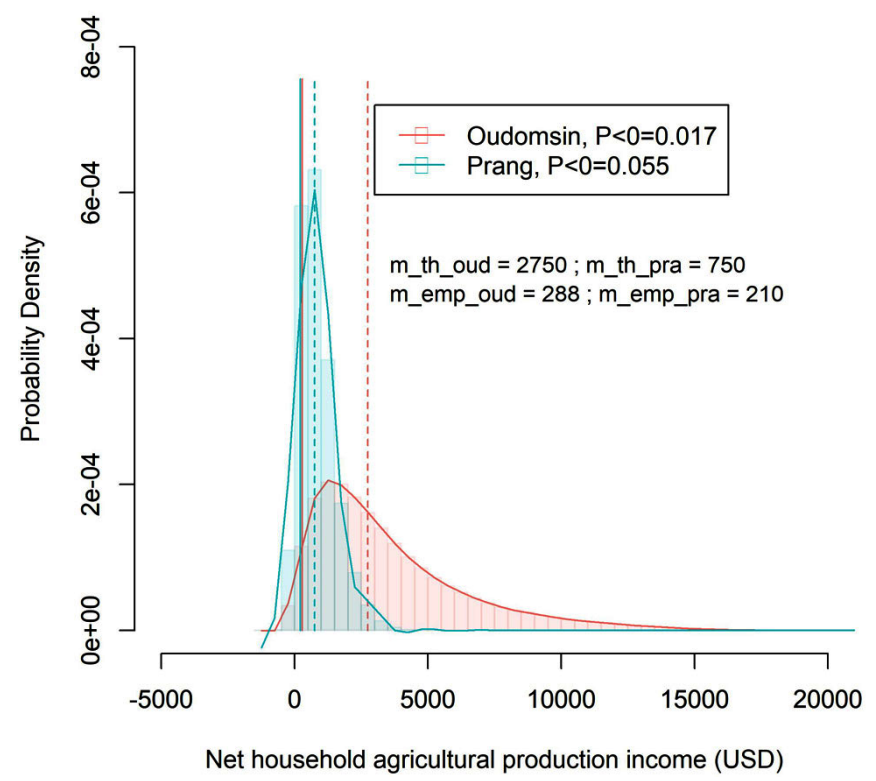

(c) High-income household

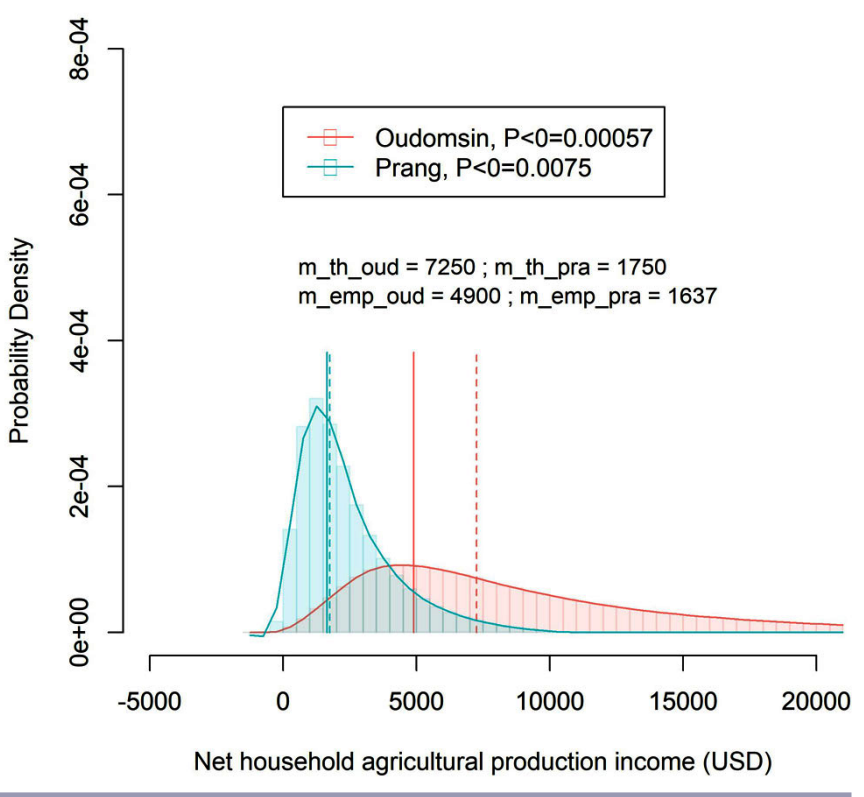

of the total income for cardamom-cultivating households in Prang (Table A1.1). The proportionally large impact of rubber production on the theoretical distribution of agricultural production income stems from the large variability in historical rubber prices and the wide range in household rubber hectares, which generates a very large theoretical income range from rubber production. In other words, rubber incomes could attain very high levels (for households with large rubber plantations and in years of high rubber prices), which overshadows the income potential from other crops. 
Oudomsin households have more rubber and are therefore more sensitive to rubber prices. A change of US\$1 per kilogram in the market price of rubber in China results in a change in median net agricultural production income of US\$1625 and US\$625 in the Oudomsin and Prang areas, respectively (Fig. 5A). Because Prang and Oudomsin households have approximately the same area of paddy rice, a change of 1 ton per hectare in rice yield results in the same change in net agricultural production income in both areas, namely US\$273 (Fig. 5B). Figure 5 also shows that median agricultural income increases linearly with increasing rubber prices and rice yields; this is expected, given the linear relationship between these variables in the $\mathrm{BN}^{[12]}$. Whereas the 25 th and 75 th income quantiles remain roughly parallel as a function of rice yield, the distance between these quantiles increases with increasing rubber prices: as rubber prices rise, the income distribution curve flattens and has especially longer positive tail ends.

Fig. 5. Sensitivity of net agricultural production income of an average Oudomsin and Prang household with zero leased paddy hectares to (A) rubber market price in China and (B) paddy rice yield. The solid line indicates median income (slopes indicated). The dashed lines indicate the $25 \%$ and $75 \%$ quantiles.
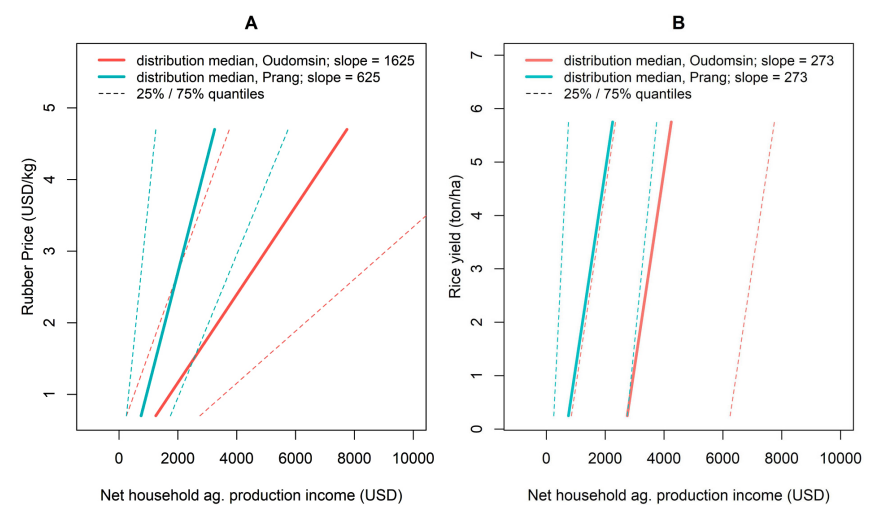

\section{Effect of diversification}

We evaluate the impact of diversification on agricultural production income for a middle-income and a low-income household representative of both CSAs (Table A1.3-C). The first thing that becomes apparent is that middle-income households, who have larger land holdings, have a very low probability of having negative net agricultural production income for all land portfolios (Fig. 6A). Reversely, certain land-use configurations entail a very large probability of falling under this threshold for low-income households (Fig. 6B).

Because revenues per hectare of cardamom are lower than for rubber, and the price of cardamom is less volatile than the price of rubber (Table A1.1), we expect that a higher share of cardamom will decrease the median and the variability of household agricultural production income. Results confirm this, both for middle- and low-income households (Fig. 6).

Increasing the share of rubber at the expense of cardamom increases income variability, which is denoted by the interquartile range $(25 \%$ to $75 \%$ of income), but it also shifts the income distribution upward, increasing the median and the 25th/75th quantiles for both household types. Interestingly, however, the probability of having negative net agricultural income is not always lower with higher shares of rubber. For a medium-income household, this probability is slightly lower for a $50 / 50 \%$ mix of rubber and cardamom despite the substantially lower median income of this portfolio, compared to $100 \%$ rubber (Fig. 6A). For a low-income household, however, diversifying between cardamom and rubber does not entail any benefits: higher shares of rubber lower the probability of having negative income in all portfolio scenarios (Fig. 6B).

These results suggest that there are instances, for example when a household has a sufficiently large agricultural area, when there is a benefit to diversifying upland cash crops between rubber and cardamom, whereas households with small agricultural areas are better off planting only rubber, the much more lucrative cash crop. Yet given the small positive effect of this diversification for middle-income households (Fig. 6A), model outputs suggest that households are generally better off planting only or mostly rubber in upland plots.

Leasing out paddy land for cash crop production instead of producing paddy rice does not have a large effect on median income. Although banana leases were roughly twice as lucrative as paddy rice production during the banana boom ${ }^{[13]}$, subsequent periods of no income and less lucrative sugarcane leases have rendered the average return to land of paddy land leases over the study period roughly equivalent to the return to land of paddy rice production (Table A1.1). However, income variability is higher for paddy leases. Leasing out paddy land for cash crop production thus entails a larger risk of falling under a negative net agricultural production income for both household types and all land-use configurations analyzed (Fig. 6A \& B). For middleincome households, this effect is minimal, given their overall low probability of having a negative net income.

A middle-income household that dedicates all agricultural land to cash crop production and purchases all of its rice has $94 \%$ likelihood or higher of having positive net agricultural production income; in other words, middle-income households are very likely to be able to make enough money from selling cash crops to cover their rice consumption needs (Fig. 6A).

For a low-income household, the likelihood of having negative net agricultural production income depends on household rice sufficiency and on the type of cash crops planted. Rice sufficiency alone is not the determining factor. For example, a household with lowland dedicated to rice paddy and upland dedicated to upland rice and cardamom, a typical household in Prang, is technically rice-sufficient, producing, on average, 0.1 excess tons of rice per person (Fig. 6B). However, this household has a $12 \%$ probability of not being able to cover household rice consumption needs, for instance during periods of low rice yields. Planting rubber instead of cardamom reduces this probability. Furthermore, dedicating all agricultural land to cash crops entails significant risk for a low-income household if cardamom is the main cash crop and if the household gives up paddy rice production; in that case, the probability of having a negative net agricultural production income is $40 \%$. A low-income household is better off dedicating its upland to rubber production, or a combination of rubber and upland rice, and retaining its paddy land for rice production. 
Fig. 6. Twenty-five percent and 75\% income quantiles (lower and upper points) and median income (central point) for different land use configurations for a (A) middle-income household and (B) low-income household representative of both case study areas. Where only two points are present, they represent the $25 \%$ and $75 \%$ income quantiles. The headings indicate household net rice production per person: positive values indicate excess rice production, and negative values indicate net rice purchase. The probability of falling under zero net agricultural production income $(\mathrm{P}<0)$ is indicated.

(A) Middle-income household

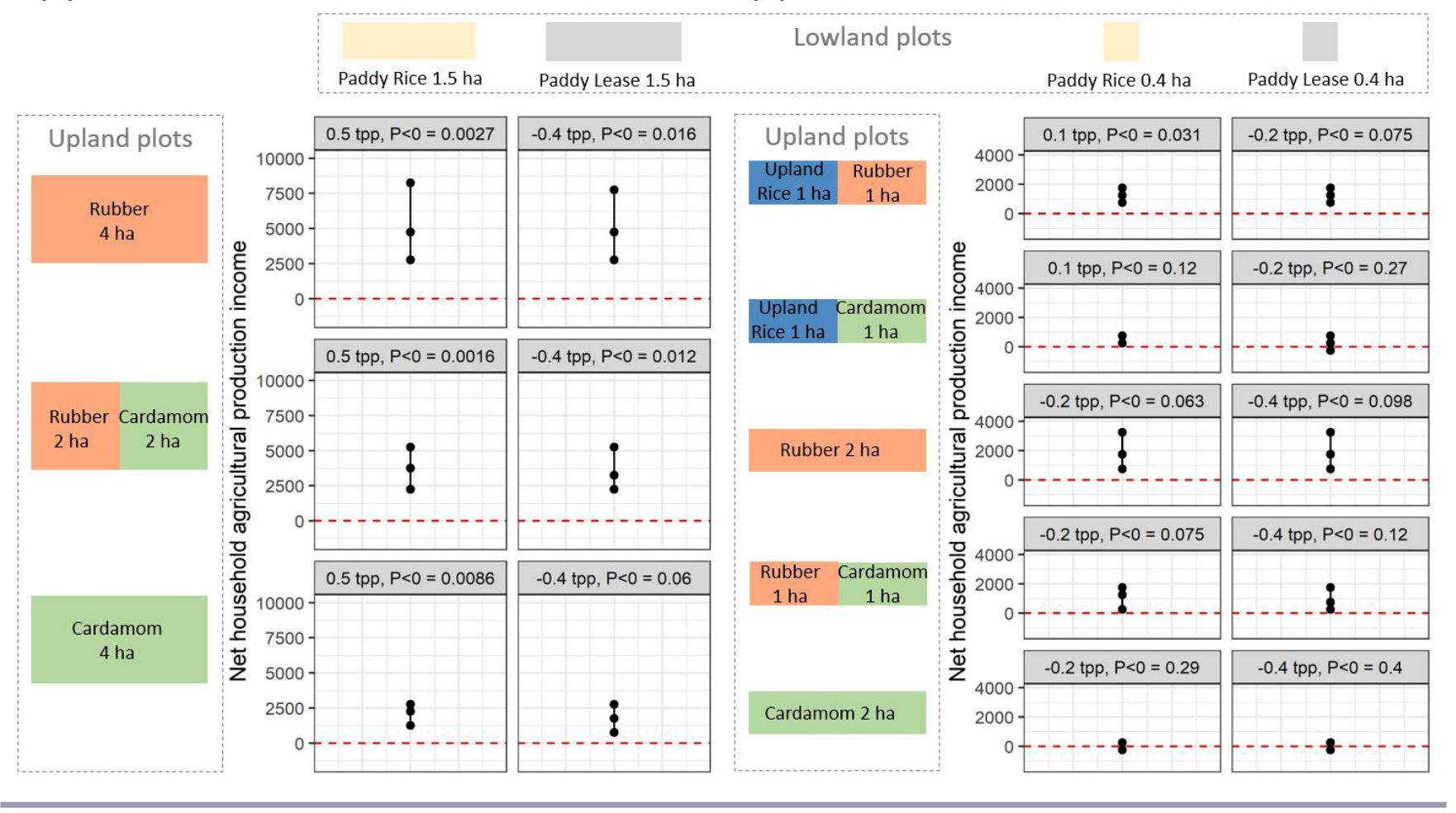

\section{(B) Low-income household}

The above results provide estimates of net household agricultural production income based on the full range of possible rubber price values. During periods of low rubber prices, as is the case since 2014 (Fig. 3), results change significantly. Figure 7 shows a scenario in which middle- and low-income households have leased out their paddy rice area for cash crop production and have planted all upland plots with rubber. When rubber prices are low (red line), the probability of having negative net agricultural production income is $6 \%$ for middle-income households (Fig. 7A) and $29 \%$ for low-income households (Fig. 7B). Thus, giving up household rice production entirely, in particular paddy rice production, entails significant risk, especially for low-income households.

\section{DISCUSSION AND CONCLUSIONS}

We propose a novel method for assessing livelihood vulnerability using a BN model of net household income, and define livelihood vulnerability as the probability of falling under an income threshold. Our methodological implementation in this work limits the analysis to net agricultural production income. Thus, it does not present a full picture of livelihood vulnerability as presented in the theoretical conceptualization.
Fig. 7. Probability distribution of net household agricultural production income when the rubber market price in China is reflected in the Bayesian network as a probability distribution (black) or set to its minimum (red) or maximum (blue) value for a (A) middle-income household and a (B) low-income household representative of both case study areas. For both household types, paddy rice area is leased for cash crop production, and upland agricultural area is planted with rubber.
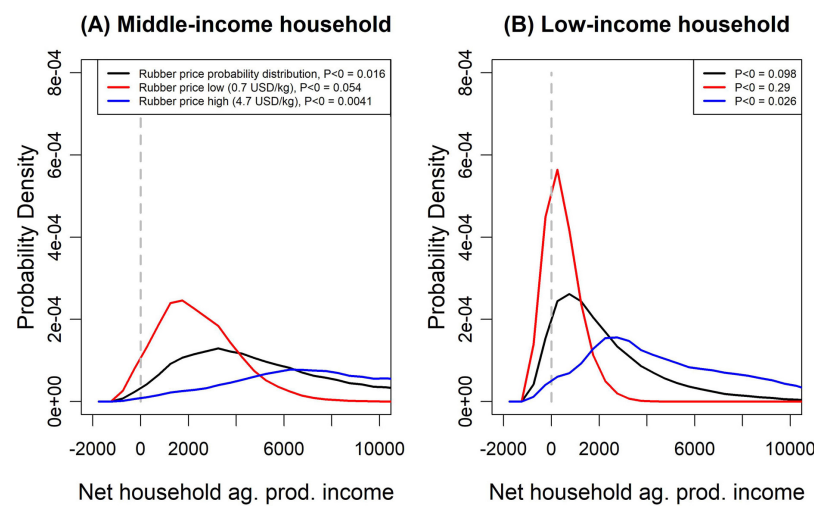
The use of a $\mathrm{BN}$ model to calculate the probability distribution of a measure of vulnerability, e.g., household income, has several advantages. It allows for a probabilistic representation of all system variables, rather than reflecting only exogenous stressors, such as crop yields or prices (e.g., Luers et al. 2003), or the outcome variable (e.g., Günther and Harttgen 2009), as a probability distribution. This allows for an explicit representation of system stressors. It also makes it possible to estimate not only the conditional moments (median and variance) of the measure of vulnerability (Cissé and Barrett 2018), but also the full probability distribution curve, without the need to assume the shape of the distribution (e.g., log-normal; Günther and Harttgen 2009). This, in turn, makes it straightforward to evaluate the cumulative probability at any threshold.

Certain controlling variables, such as soil quality, are implicit in the model and reflected in the probability distribution of crop yields. Yet the modularity of BNs makes it possible to explicitly incorporate such variables, e.g., by linking soil quality to yield, without changing the BN structure or parameterization. Fixing variable values automatically recalculates the (conditional) probability distributions of all other variables in the $\mathrm{BN}$, allowing for straightforward and transparent sensitivity and scenario analyses. Here, we use this property to determine the sensitivity of household income to other variables in the model, to run scenarios for different rubber price levels, and to run scenarios for different land portfolios. We use the same BN to calculate the income distribution at the level of the household and at the level of the case study area by instantiating, or not, household-level variables, which demonstrates the versatility of the $\mathrm{BN}$.

From a policy perspective, this approach can be used to identify the household types that have the highest potential to benefit from agricultural commercialization (Siegel 2008) and those that require additional strategies for poverty reduction, such as safety nets - a relevant policy consideration, given that vulnerability tends to perpetuate poverty (Barrett and McPeak 2006, Imai et al. 2011). The explicit and graphical representation of income distribution curves makes it straightforward to visualize income inequalities, e.g., between household types or case study areas. Furthermore, the BN property of forward- and backwardpropagation makes it possible to ascertain the necessary configuration of system variables to attain a desired outcome.

The explicit representation and propagation of uncertainty and variability in BNs (Uusitalo 2007, Stritih et al. 2019) makes them particularly useful for risk and resilience assessments (Fenton and Neil 2018). Along the same line, they are useful tools to disaggregate sources of uncertainty and variability. Here, we draw on these properties to show how temporal variability (volatility) of international market prices, combined with local price variability (caused by seasonal changes, differences in transport, traders, etc.) results in a local probability distribution of crop prices that is reflective of both temporal and cross-sectional variability. The $\mathrm{BN}$ thus explicitly shows the propagation and amplification of price variability through the supply chain, which makes BNs interesting tools for the analysis of price volatility. We further use the $\mathrm{BN}$ to separate measurement error, e.g., in reported rice yields, from other sources of yield variability. We do not eliminate measurement error from household variables or other crop yields, but expect it to be small for those variables.
Whereas this approach captures many of the elements of socioeconomic vulnerability, it also leaves out important ones, such as adaptive capacity and learning (Holling 2001, Folke et al. 2002, Berkes 2007), and broader dimensions of livelihoods (Scoones 2009).

\section{Effect of cash crops on agricultural income}

We apply this methodology in two CSAs that are at different stages of an agricultural transition and frontier evolution. Whereas both areas remain largely rice self-sufficient, Oudomsin households have larger shares of agricultural area dedicated to cash crop production, particularly in the uplands; in contrast, shifting cultivation is still the dominant upland land-use in the Prang area. Similar to other studies on rural livelihoods that report a significant rise in household income after the adoption of cash crops (e.g., Ahmed et al. 2010, Griffin 2019), particularly rubber (Sturgeon 2013), we find that households with more rubber hectares, as is the case for Oudomsin households, have higher incomes. Because of the volatility of rubber prices, these households also have higher income variability. Despite this, Oudomsin households have a lower probability of having a negative net agricultural production income compared to Prang households. These findings are similar for high-income and lowincome households.

These results do not imply that a household should convert all of its agricultural land to cash crops. Rather, Oudomsin households have a lower probability of falling under an agricultural income threshold mostly because they have larger agricultural areas dedicated to food and cash crop production. In fact, a main result from our analysis is that households with larger land holdings have a low probability of not being able to meet their food consumption needs regardless of land portfolio. These results confirm findings that the size of land holdings is a main determinant in land use poverty traps (Coomes et al. 2011). Similarly, Abson et al. (2013) find that a larger agricultural area increases farmers' economic resilience, especially for lowerincome farms. Our results further point at an indirect beneficial effect of household size, since larger households tend to have larger agricultural areas in the CSAs analyzed. In addition, we find that maintaining a minimum level of rice sufficiency is important, especially for low-income households, as discussed below.

\section{Effects of diversification}

Livelihood diversification per se does not necessarily have a positive impact on livelihood outcomes (Gautam and Andersen 2016, Asfaw et al. 2019). In fact, it can have negative outcomes if it deters households from saving for investment purposes (Hussein and Nelson 1998). However, diversification is believed to reduce the overall risk if it reduces the covariance among different sources of stress or shock (Scoones 1998). Agricultural diversity theoretically reduces income variability if commodity prices are not correlated (Quiroz and Valdés 1995). In fact, agricultural landscape diversification between uncorrelated commodities has been shown to decrease income volatility and increase economic resilience, despite reducing agricultural margins (Abson et al. 2013). Crop diversification also has a positive impact on resilience because crops respond differently to biophysical stressors, such as adverse weather conditions (Di Falco and Chavas 2008). Thus, given a certain amount of agricultural land, crop diversification 
should reduce income volatility because of the unlikelihood that all commodities will suffer a price drop or crop failure at the same time (Adger 2000, Abson et al. 2013).

In our BN model, crop prices are represented as being independent from each other, that is, they are not linked. In theory, this reflects the best possible scenario for the positive effects of diversification. Based on the discussion above, we assume that increasing diversification in upland cash crops by partly replacing a high-value crop, such as rubber, with a crop with lower returns but lower price volatility, such as cardamom, would reduce the likelihood of having a negative agricultural income. Results only partially confirm this. Increasing the share of cardamom at the expense of rubber given a fixed amount of upland cash crop area reduces both median income and income variability. This diversification brings small benefits for middle-income households and no benefits for low-income households. In this case, the benefit from the lower income variability associated with cardamom does not outweigh the benefit of the much higher median income associated with rubber. Indeed, the theoretical income range of rubber $(3940 \pm 5500)$ is so large compared with that of cardamom $(110 \pm 150)$ that it overshadows cardamom revenue in the analysis. This is an important, albeit trivial, insight: the model suggests that diversification is more beneficial if the income potential associated with the additional crop is comparable to that of the original crop.

These results should be interpreted carefully and in light of certain limitations of the $\mathrm{BN}$ model. We implement crop price volatility by taking into account historical market prices over a multiyear period (e.g., a 22-year period for rubber). In reality, however, commodity prices generally do not jump from a 22-year high to a 22-year low in one single year. In this sense, the $\mathrm{BN}$ overemphasizes the variability that is caused by price volatility. This, in turn, overshadows the impact of other variables on income variability. An alternative would be to implement commodity price distributions that are conditional on the prior year's prices. However, addressing this issue would make rubber "look even better," because it would reduce its effect on income variability without affecting its effect on median income. This structural limitation of the model does not apply to commodity yields, which can indeed oscillate between extremes from one year to the next.

A further limitation is the scarcity of empirical rubber yield data, given that rubber trees are still relatively young in both CSAs. Conducting this assessment in 5 to 10 years would allow to better reflect the variability of rubber monoculture yields, including pest-induced harvest losses. In fact, rubber plantations in Oudomsin were affected by pests in late 2017, but this is not reflected in the yield data. Cardamom yields, in contrast, have shown to be relatively stable. Including longer term crop yield data might tip the balance in favor of cardamom and affect the conclusions from the diversification analysis.

Furthermore, the discretization of the outcome variable in the $\mathrm{BN}$ is done in US\$500 intervals to accommodate the very large potential income range (-US\$5000 - US\$110,000). Thus, changes that affect net agricultural income by less than this amount are not reflected in the model output. However, US\$500 is a large amount, especially in the Prang area. Hence, a finer discretization in the lower income brackets would help nuance the results of the diversification analysis.

\section{Effects of rice sufficiency}

We expect higher levels of rice sufficiency to reduce the probability that a household will not be able to cover rice consumption needs with cash crop sales because the variability of rice production, particularly paddy rice, is lower than the variability of cash crop revenue. Results from the sensitivity analysis show that household income is indeed less sensitive to paddy rice yield than to rubber yield or rubber price. Results further show that maintaining a minimum level of household rice production, especially from high-yielding paddy, is important for households with little agricultural land and for households with only low-value cash crops such as cardamom, essentially, low-income households. A low-income household that has converted all of its agricultural land to cash crops has a significant probability of having a negative agricultural income. Although this household can more easily meet its rice consumption needs if the upland cash crop is rubber rather than cardamom, it will most likely not be able to cover its food consumption needs during periods of low rubber prices. This household would be better off if it had retained its paddy land for rice production. For households that have larger agricultural areas, maintaining a minimum level of rice sufficiency is less critical.

In an analysis of the effects of diversification on rural household incomes in sub-Saharan Africa, Asfaw et al. (2019) similarly find that diversification benefits poor households more. However, the study does not distinguish between crop types. Our analysis specifically suggests the benefit of allocating a share of the land portfolio to food crops for household consumption, especially in the case of low-income households. These findings are in line with studies showing the vulnerability of households that are net food buyers during periods of high food prices (de Janvry and Sadoulet 2011).

\section{Limitations of this approach and broader aspects of livelihood vulnerability}

Certain limitations of the $\mathrm{BN}$ model structure and parameterization result in an incomplete and approximate quantification of household income. The most important limitation of the model is that it only addresses agricultural production income. A full assessment of livelihood vulnerability as defined herein (Fig. 1) should account for additional relevant income streams and expenses (Fig. 2). Rural households in developing countries undergoing agricultural transitions increasingly rely on a combination of agricultural and nonagricultural activities, remittances, and migration (Block and Webb 2001, Rigg 2005, 2006, Reardon et al. 2007, Gautam and Andersen 2016, Martin and Lorenzen 2016). We did not systematically quantify migration but found that a number of households had one or more members working in a different province or in China or Thailand. Nonagricultural income composes an important and growing source of income in both CSAs. Remittances were negligible in 2017, but we suspect that they may increase during periods of financial stress or agricultural expansion. Beyond remittances, we do not include other income streams traditionally used for consumption smoothing, such as insurance, borrowing, and labor wages. Although insurance is not available in the two study areas, borrowing is a frequent and important source of auxiliary funding. Many households engage flexibly in agricultural and nonagricultural labor, depending on necessity and availability. These income streams are highly 
variable throughout the population and not accessible to all villagers, but leaving them out misses an important component of households' ability to cope with stress. Studies that use household consumption, rather than income, as a metric of vulnerability implicitly address coping ability (Kamanou and Morduch 2002).

From a resilience perspective, the relevance of considering not only flows, but also stocks, has been recognized (Walker et al. 2010). Having enough stocks ensures uninterrupted flows, whose disruption (e.g., failed harvest, loss of income, lack of irrigation water) would mean severe damage to the system (Luers et al. 2003, Walker et al. 2010). Our model does not include livelihood stocks such as rice reserves, capital assets, cattle, and cash savings (Table A1.4), despite the fact that these are important contributors to household resilience through income smoothing (Scoones 1998).

The $\mathrm{BN}$ does not include household expenses other than rice consumption. However, idiosyncratic shocks, and health shocks in particular, have sizable adverse effects on households, especially on low-income households. Indeed, health shocks frequently have a higher impact than natural or economic shocks in developing countries (Dercon et al. 2005, Yilma et al. 2014), including in Laos (Wagstaff and Lindelow 2014). This is also the case in Oudomsin and Prang, where the most frequently mentioned household economic shocks were large unplanned household expenses associated with medical illness or funeral costs. Furthermore, our model does not account for the fact that household expenses may grow with an increasing standard of living. We also do not include expenses associated with agricultural production, such as inputs. Although these expenses (e.g., fertilizer, pesticide, gasoline) are small compared with crop revenues, including them would allow to make more solid claims about the probability distribution of net agricultural production income.

The focus on agricultural production misses important aspects around labor allocation and its relationship with households' land use portfolio. For example, leasing paddy land instead of producing rice releases labor that can be allocated to other activities. The high proportion of off-farm income in Oudomsin might reflect this process, given that a majority of households leased their paddies during and after the banana boom. Conversely, labor allocation into cash crop production can negatively affect other livelihood sources. Labor allocation could be incorporated into the model by adding a household labor variable that depends on land use and that assumes an average salary. For instance, leasing a 0.5 ha paddy could free up roughly 25 annual workdays, which is equivalent to 1.5 million KIP (US\$190), assuming agricultural day wages of 60,000 KIP (US\$7.5). This improved model would still not address labor market changes in agricultural transitions. For instance, the banana boom in the Oudomsin area created local job opportunities in banana plantations with annual salaries of 6000 Chinese Yuan (US\$900).

Most of the above-mentioned shortcomings could be addressed by expanding the boundary of the BN model. Additionally, the proposed methodology has a number of structural limitations. This approach does not account for emergent properties, such as learning or adaptation, which are essential components of socialecological vulnerability (Holling 2001, Folke et al. 2002, Berkes
2007). Although BNs have been suggested for social learning applications (e.g., Kelly et al. 2013), it is because of their ability to help model users learn, rather than their ability to model social learning. In our model, households' ability to learn and adapt could be incorporated by adding related variables, such as education or social capital, if they are found to be correlated with other model variables, such as yields. However, this does not overcome the inability of BNs to predict fundamental socialecological shifts, given that they are based on trends from past observations (Brown et al. 2013). Moreover, our model implements a simplified relationship between biophysical and economic dimensions (in this case, a linear effect of yield on income), missing more complex interactions between economic, biophysical, and cultural factors and their effect on livelihood resilience (Lade et al. 2017). Our approach also does not account for actors' diversity (Grêt-Regamey et al. 2019) or relational resilience (Darnhofer et al. 2016), which are important aspects of landscape and farm-level resilience. Indeed, leaving out social and kinship relations ignores a very important element of household resilience, as household interviews revealed the importance of borrowing and knowledge transmission between kin. Our methodology also leaves out important socio-political aspects such as power imbalances, for instance among farmers, between farmers and local governments, and between farmers and traders (Zuo et al. 2020).

By focusing only on income streams and cash flows, this approach does not capture broader dimensions of livelihoods. Livelihood frameworks recognize the activities, capabilities, and assets or capitals (financial, human, natural, physical, and social) required to make a living (Sen 1984, Chambers and Conway 1992, Scoones 1998, De Haan and Zoomers 2005), including claims and access to those resources (Ribot and Peluso 2003, Kronenburg García and van Dijk 2019). Various studies have documented the processes of dispossession that restrict farmers' access to these livelihood assets, for instance through "land grabs" (e.g., Hall et al. 2011, Kenney-Lazar 2012). In Oudomsin and Prang, subtler access limitations are taking place. The expansion of rubber plantations around village centers has increased the traveling distance to the forest and has reduced the area of shifting cultivation fallows and communal land. Among other consequences, this has restricted villagers' access to forest resources, such as nontimber forest products (NTFPs). Restricted access to forests, which have traditionally supplemented food, material, and cash flow for many upland populations (Jakobsen 2006, Castella et al. 2013, Russell et al. 2015), increases the vulnerability especially of the poorest households (Agarwal 1991), who are the most reliant on NTFPs as additional sources of nutrition and cash. Land use policies favoring cash crops have also reduced the available grazing land and reduced or eliminated the number of cattle and buffalo (Junquera and Grêt-Regamey 2019, Rousseau and Sturgeon 2019), which were traditionally important household assets and remain an important coping strategy. Furthermore, the expansion of commercial monocrop plantations has also caused a net loss of biodiversity and ecosystem services in both CSAs, including decreasing soil fertility (Steiger 2019). This reduces landscape resilience (Castella et al. 2013) and introduces new vulnerabilities associated with increased dependency on inputs, such as pesticides and fertilizers (Rigg et al. 2016, Ornetsmüller et al. 2018, Griffin 2019). 
Although property regimes and ecological resilience are not addressed in the $\mathrm{BN}$, the model could be adapted to reflect access to forest-based provisioning services such as NTFPs, hunting, or fishing.

Finally, some households have no social safety net, be it because they are newcomers, perceived as lazy or alcoholics, or for other reasons. For these households, a sudden expense or shock frequently entails selling their last agricultural plot and becoming destitute, especially because communal or unclaimed land is increasingly scarce in Prang and virtually nonexistent in Oudomsin. These cases are a "probabilistic minority," which is overshadowed in our analysis. Their importance is not to be underestimated in processes of land commodification that can contribute, along with other factors, to increasing wealth disparities within communities, especially when no institutional buffering measures (e.g., farm insurance, price controls, or social security) are available.

Other studies have pointed out the importance of state support for smallholder farmers (de Janvry and Sadoulet 2011, Byerlee 2014), especially during low-price periods (Vongvisouk and Dwyer 2017). Affordable and state-supported healthcare, education, insurance, and other contingency measures, such as low-interest loans that do not use agricultural land as collateral, would provide essential safety nets and leave smallholder farmers less exposed to market or idiosyncratic shocks, especially in light of increasing pest-induced harvest failures and the recent slump in rubber prices.

Despite its limitations, the proposed approach offers numerous insights and advantages. The use of a $\mathrm{BN}$ makes it possible to explicitly model sensitivity and exposure to stressors and allows for a flexible integration of model variables. We demonstrate how this approach can be used to identify vulnerable household types or regions, shed light on the major sources of income volatility, and help identify optimal diversification strategies. By explicitly and flexibly representing income streams and associated variables, this approach can also be used to help design policy instruments that can act as safety nets.

[1] Variously referred to as agrarian or agricultural transition, transformation, commercialization, or commodification (Byres 1977, von Braun 1995, Bernstein and Byres 2001).

${ }^{[2]}$ Note that sensitivity is sometimes classified as external, e.g., in Luers et al. (2003).

[3] Land use history and village demographics and ethnic composition are described in Junquera and Grêt-Regamey (2019).

${ }^{[4]}$ Based on 2005 Laos census data and subject to large uncertainty given that we were not able to identify all the villages precisely; includes populations for Nam Det Kao (which we assume is Nam Det Somboun before relocation), Oudomsin, Nam Det Mai, Nam Mai, Donechai, Pakha, Punko, Chongkar (part of later Phoudonetan), Say Leck (part of later Phoudonetan), Sop I Mai (which we assume is Sop-I), and Lakham. Phoudonetan village is composed of relocated Hoi Dam, Chongkar, and Say Leck but we could not find Hoi Dam in the Census.

${ }^{[5]}$ In 2017, Akha ethnic villages surveyed tended to manage their own sugarcane plantations, whereas Yao villages tended to lease their sugarcane plots to Akha villagers.
${ }^{[6]}$ Yao ethnic villages in particular have revenues from handicraft sales in the United States through kinship networks.

${ }^{\text {[7] }}$ Based on 2005 Laos census data for Talong, Palang (Prang), Namlung, and Namsing, all in Vieng Poukha District. We do not have access to Laos census data for Namtha District, so we use the 2017 population for Khosung, which was elicited in the village focus group. The 2017 population for the case study area was 1509 (Junquera and Grêt-Regamey 2019).

${ }^{[8]}$ Selected villages in the Oudomisn area belong to Akha $(\mathrm{N}=3)$ and Yao $(\mathrm{N}=3)$ ethnic groups.

${ }^{[9]}$ Villages in the Prang area belong to the Khmu ethnic group.

${ }^{[10]}$ Employees of rubber companies in Laos obtain information about Chinese rubber market prices, e.g., on their smartphones, through the internet, or through direct communication with Chinese company headquarters.

${ }^{[11]}$ Paddy rice can be glutinous or nonglutinous; in Laos most rice produced is glutinous (Bestari et al. 2006).

${ }^{[12]}$ We assume that these relationships are also linear in reality. However, in the case of rice yield, nonlinearities could arise in the case of a nonlinear relationship between rice yield and rice production costs, for instance because of higher input use per unit of yield. Production costs are not accounted for in the BN, but they could be added.

${ }^{[13]}$ Paddy land leases for banana plantations commanded roughly 2000 U\$/ha/year during the banana boom in Oudomsin, although leases varied with plot quality and year.

Responses to this article can be read online at: https://www.ecologyandsociety.org/issues/responses. php/12049

\section{Acknowledgments:}

The authors would like to thank M. Dwyer and J. Lu for their help on rubber price formation and transmission in China and Laos; and P. Meyfroidt, Y. le Polain de Waroux, and K. Harttgen for their helpful suggestions on the manuscript. This work was supported by the Swiss Programme for Research on Global Issues for Development (R4D Programme), funded by the Swiss National Science Foundation (SNSF) and the Swiss Agency for Development and Cooperation (SDC), grant number 400440 152167.

\section{Data Availability:}

The datalcode that support the findings of this study are available on request from the corresponding author, VJ. The datalcode are not publicly available because they contain information that could compromise the privacy of research participants. This study did not require institutional approval for human subjects research according to ETH Zurich regulations.

\section{LITERATURE CITED}

Abson, D. J., E. D. G. Fraser, and T. G. Benton. 2013. Landscape diversity and the resilience of agricultural returns: a portfolio analysis of land-use patterns and economic returns from lowland agriculture. Agriculture and Food Security 2:2. https://doi. org/10.1186/2048-7010-2-2 
Adger, W. N. 2000. Social and ecological resilience: are they related? Progress in Human Geography 24(3):347-364. https://doi. org/10.1191/030913200701540465

Adger, W. N. 2006. Vulnerability. Global Environmental Change 16:268-281. https://doi.org/10.1016/j.gloenvcha.2006.02.006

Agarwal, B. 1991. Social security and the family: coping with seasonality and calamity in rural India. Pages 184-185 in E. Ahmad, J. Drèze, J. Hills, and A. Sen, editors. Social security in developing countries. Oxford University Press, Oxford, UK. https://doi.org/10.1093/acprof:oso/9780198233008.003.0005

Ahmed, S., J. R. Stepp, R. A. J. Toleno, and C. M. Peters. 2010. Increased market integration, value, and ecological knowledge of tea agro-forests in the Akha highlands of southwest China. Ecology and Society 15(4):27. https://doi.org/10.5751/ES-03728-150427

Alkire, S., and M. E. Santos. 2014. Measuring acute poverty in the developing world: robustness and scope of the multidimensional poverty index. World Development 59:251-274. https://doi.org/10.1016/j.worlddev.2014.01.026

Anderson, E. L., and D. Hattis. 1999. A. Uncertainty and variability. Risk Analysis 19(1):47-68.

Andreevska, D. L., and E. Simeonovska. 2012. Dressing percentage and yield of white rice in "Bianca" and "Galileo" two new introduced rice varieties (Oryza sativa L.) grown under agro-ecological conditions of Macedonia. Proceedings of the 4th Congress of Ecologists of Macedonia with International Participation. Macedonian Ecological Society, Ohrid, Macedonia.

Asfaw, S., A. Scognamillo, G. Di Caprera, N. Sitko, and A. Ignaciuk. 2019. Heterogeneous impact of livelihood diversification on household welfare: cross-country evidence from sub-Saharan Africa. World Development 117:278-295. https://doi.org/10.1016/ j.worlddev.2019.01.017

Banerjee, A. V., and E. Duflo. 2007. The economic lives of the poor. Journal of Economic Perspectives 21(1):141-168. https://doi. org/10.1257/jep.21.1.141

Barrett, C. B. 2008. Smallholder market participation: concepts and evidence from eastern and southern Africa. Food Policy 33 (4):299-317. https://doi.org/10.1016/j.foodpol.2007.10.005

Barrett, C. B., and J. G. McPeak. 2006. Poverty traps and safety nets. Pages 131-154 in A. de Janvry and R. Kanbur, editors. Poverty, inequality and development. Springer, Boston, Massachusetts, USA. https://doi.org/10.1007/0-387-29748-0 8

Begg, S. H., M. B. Welsh, and R. B. Bratvold. 2014. Uncertainty vs. variability: What's the difference and why is it important? SPE Hydrocarbon Economics and Evaluation Symposium Houston, Texas. Society of Petroleum Engineers, Richardson, Texas, USA. https://doi.org/10.2118/169850-ms

Berkes, F. 2007. Understanding uncertainty and reducing vulnerability: lessons from resilience thinking. Natural Hazards 41(2):283-295. https://doi.org/10.1007/s11069-006-9036-7

Bernstein, H., and T. J. Byres. 2001. From peasant studies to agrarian change. Journal of Agrarian Change 1(1):1-56. https:// doi.org/10.1111/1471-0366.00002
Bestari, N. G., S. Shrestha, and C. J. Mongcopa. 2006. Lao PDR: An evaluation synthesis on rice. A case study from the 2005 Sector Assistance Program evaluation for the agriculture and natural resources sector in the Lao People's Democratic Republic. Asian Development Bank, Operations Evaluation Department, Manila, Philippines. [online] URL: https://www.adb.org/sites/ default/files/evaluation-document/35927/files/evaluation-synthesisrice-lao.pdf

Birdsall, N., and C. J. Meyer. 2015. The median is the message: a good enough measure of material wellbeing and shared development progress. Global Policy 6(4):343-357. https://doi. org/10.1111/1758-5899.12239

Block, S., and P. Webb. 2001. The dynamics of livelihood diversification in post-famine Ethiopia. Food Policy 26:333-350. https://doi.org/10.1016/S0306-9192(01)00015-X

Brown, D. G., P. H. Verburg, R. G. Pontius, and M. D. Lange. 2013. Opportunities to improve impact, integration, and evaluation of land change models. Current Opinion in Environmental Sustainability 5(5):452-457. https://doi.org/10.1016/ j.cosust.2013.07.012

Byerlee, D. 2014. The fall and rise again of plantations in tropical Asia: history repeated? Land 3:574-597. https://doi.org/10.3390/ land3030574

Byres, T. J. 1977. Agrarian transition and the agrarian question. Journal of Peasant Studies 4(3):258-274. https://doi. org/10.1080/03066157708438024

Castella, J. C., G. Lestrelin, C. Hett, J. Bourgoin, Y. R. Fitriana, A. Heinimann, and J. L. Pfund. 2013. Effects of landscape segregation on livelihood vulnerability: moving from extensive shifting cultivation to rotational agriculture and natural forests in northern Laos. Human Ecology 41(1):63-76. https://doi. org/10.1007/s10745-012-9538-8

Chambers, R. 1989. Editorial introduction: vulnerability, coping and policy. IDS Bulletin 20(2):1-7. https://doi.org/10.1111/ j.1759-5436.1989.mp20002001.x

Chambers, R., and G. R. Conway. 1992. Sustainable rural livelihoods: practical concepts for the 21st century. IDS Discussion Paper 296. Institute of Development Studies, Brighton, UK.

Chang, C.-C., and C.-C. Chen. 2005. The impact of weather on crop yield distribution in Taiwan: some new evidence from panel data models and implications for crop insurance. Agricultural Economics 33:503-511. https://doi.org/10.1111/j.1574-0864.2005.00097. $\underline{\mathrm{X}}$

Christiaensen, L. J., and K. Subbarao. 2005. Towards an understanding of household vulnerability in rural Kenya. Journal of African Economies 14(4):520-558. https://doi.org/10.1093/jae/ eji008

Cissé, J. D., and C. B. Barrett. 2018. Estimating development resilience: a conditional moments-based approach. Journal of Development Economics 135(236):272-284. https://doi.org/10.1016/ j.jdeveco.2018.04.002

Coomes, O. T., Y. Takasaki, and J. M. Rhemtulla. 2011. Landuse poverty traps identified in shifting cultivation systems shape long-term tropical forest cover. Proceedings of the National 
Academy of Sciences of the United States of America 108 (34):13925-13930. https://doi.org/10.1073/pnas.1012973108

Darnhofer, I., C. Lamine, A. Strauss, and M. Navarrete. 2016. The resilience of family farms: towards a relational approach. Journal of Rural Studies 44:111-122. https://doi.org/10.1016/j. jrurstud.2016.01.013

De Haan, L., and A. Zoomers. 2005. Exploring the frontier of livelihood research. Development and Change 36:27-47. https:// doi.org/10.1111/j.0012-155X.2005.00401.X

de Janvry, A., and E. Sadoulet. 2010. Agricultural growth and poverty Reduction: additional evidence. World Bank Research Observer 25(1):1-20. https://doi.org/10.1093/wbro/lkp015

de Janvry, A., and E. Sadoulet. 2011. Subsistence farming as a safety net for food-price shocks. Development in Practice 21 (4-5):472-480. https://doi.org/10.1080/09614524.2011.561292

De Koninck, R. 2004. The challenges of the agrarian transition in Southeast Asia. Labour, Capital and Society 37:285-288.

de Roest, K., P. Ferrari, and K. Knickel. 2018. Specialisation and economies of scale or diversification and economies of scope? Assessing different agricultural development pathways. Journal of Rural Studies 59:222-231. https://doi.org/10.1016/j.jrurstud.2017.04.013

Dercon, S., J. Hoddinott, and T. Woldehanna. 2005. Shocks and consumption in 15 Ethiopian villages, 1999-2004. Journal of African Economies 14(4):559-585. https://doi.org/10.1093/jae/ eji022

Di Falco, S., and J.-P. Chavas. 2008. Rainfall shocks, resilience, and the effects of crop biodiversity on agroecosystem productivity. Land Economics 84(1):83-96. https://doi.org/10.3368/ $\underline{\text { le.84.1.83 }}$

Dressler, W. H., D. Wilson, J. Clendenning, R. Cramb, R. Keenan, S. Mahanty, T. B. Bruun, O. Mertz, and R. D. Lasco. 2017. The impact of swidden decline on livelihoods and ecosystem services in Southeast Asia: a review of the evidence from 1990 to 2015. Ambio 46:291-310. https://doi.org/10.1007/s13280-016-0836-Z

FAOSTAT. 2020. Producer price indices (Rice, paddy; Lao People's Democratic Republic; Producer Price Index). Food and Agriculture Organization, Rome, Italy. [online] URL: http://www. fao.org/faostat/en/\#data/PP

Fenton, N., and M. Neil. 2018. Risk assessment and decision analysis with Bayesian networks. Second edition. Chapman and Hall/CRC, Boca Raton, Florida, USA.

Folke, C., J. Colding, and F. Berkes. 2002. Synthesis: building resilience and adaptive capacity in social-ecological systems. Pages 352-387 in F. Berkes, J. Colding, and C. Folke, editors. Navigating social-ecological systems. Cambridge University Press, Cambridge, UK. https://doi.org/10.1017/CBO9780511541957.020

Friis, C., and J. Ø. Nielsen. 2016. Small-scale land acquisitions, large-scale implications: exploring the case of Chinese banana investments in northern Laos. Land Use Policy 57(30):117-129. https://doi.org/10.1016/j.landusepol.2016.05.028

Friis, C., and J. Ø. Nielsen. 2017. Land-use change in a telecoupled world: the relevance and applicability of the telecoupling framework in the case of banana plantation expansion in Laos. Ecology and Society 22(4):30. https://doi.org/10.5751/es-09480-220430

Gautam, Y., and P. Andersen. 2016. Rural livelihood diversification and household well-being: insights from Humla, Nepal. Journal of Rural Studies 44:239-249. https://doi. org/10.1016/j.jrurstud.2016.02.001

Goharian, E., S. J. Burian, and M. Karamouz. 2018. Using joint probability distribution of reliability and vulnerability to develop a water system performance index. Journal of Water Resources Planning and Management 144(2):1-12. https://doi.org/10.1061/(ASCE) $\underline{\text { WR.1943-5452.0000869 }}$

Grêt-Regamey, A., S. H. Huber, and R. Huber. 2019. Actors' diversity and the resilience of social-ecological systems to global change. Nature Sustainability 2:290-297. https://doi.org/10.1038/ s41893-019-0236-Z

Griffin, C. 2019. 'Prosperity beyond belief': the interaction between a potato crop boom, vulnerability and volcanic hazard in Central Java, Indonesia. Singapore Journal of Tropical Geography 41(1):23-39. https://doi.org/10.1111/sjtg.12294

Günther, I., and K. Harttgen. 2009. Estimating households vulnerability to idiosyncratic and covariate shocks: a novel method applied in Madagascar. World Development 37 (7):1222-1234. https://doi.org/10.1016/j.worlddev.2008.11.006

Hahn, M. B., A. M. Riederer, and S. O. Foster. 2009. The livelihood vulnerability index: a pragmatic approach to assessing risks from climate variability and change - A case study in Mozambique. Global Environmental Change 19:74-88. https://doi. org/10.1016/j.gloenvcha.2008.11.002

Hall, D., P. Hirsch, and T. M. Li. 2011. Powers of exclusion: land dilemmas in Southeast Asia. NUS Press, Singapore.

Harvey, C. A., Z. L. Rakotobe, N. S. Rao, R. Dave, H. Razafimahatratra, R. H. Rabarijohn, H. Rajaofara, and J. L. Mackinnon. 2014. Extreme vulnerability of smallholder farmers to agricultural risks and climate change in Madagascar. Philosophical Transactions of the Royal Society B: Biological Sciences 369(1639). https://doi.org/10.1098/rstb.2013.0089

Heinimann, A., O. Mertz, S. Frolking, A. E. Christensen, K. Hurni, F. Sedano, L. P. Chini, R. Sahajpal, M. Hansen, and G. Hurtt. 2017. A global view of shifting cultivation: recent, current, and future extent. PLOS ONE 12(9):e0184479. https://doi. org/10.1371/journal.pone.0184479

Hennessy, D. A. 2009. Crop yield skewness and the normal distribution. Journal of Agricultural and Resource Economics 34 (1):34-52.

Hirsch, P. 2009. Revisiting frontiers as transitional spaces in Thailand. Geographical Journal 175(2):124-132. https://doi. org/10.1111/j.1475-4959.2009.00321.X

Holling, C. S. 2001. Understanding the complexity of economic, ecological, and social systems. Ecosystems 4(5):390-405. https:// doi.org/10.1007/s10021-001-0101-5

Hozo, S. P., B. Djulbegovic, and I. Hozo. 2005. Estimating the mean and variance from the median, range, and the size of a sample. BMC Medical Research Methodology 5:1-10. 
Hussein, K., and J. Nelson. 1998. Sustainable livelihoods and livelihood diversification. IDS Working Paper 69. Institute of Development Studies, Brighton, UK.

Imai, K. S., R. Gaiha, and W. Kang. 2011. Vulnerability and poverty dynamics in Vietnam. Applied Economics 43 (25):3603-3618. https://doi.org/10.1080/00036841003670754

Indexmundi. 2020. Rubber (Asia, RSS3 grade), Monthly price (Yuan Renminbi per kilogram), Singapore Commodity Exchange Ltd (SICOM). https://www.indexmundi.com/commodities/? $\underline{\text { commodity }=\text { rubber } \& \text { months }=240 \& \text { currency }=\mathrm{cny}}$

Jakobsen, J. 2006. The role of NTFPs in a shifting cultivation system in transition: a village case study from the uplands of North Central Vietnam. Geografisk Tidsskrift 106(2):103-114. https://doi.org/10.1080/00167223.2006.10649560

Joshi, P. K., A. Gulati, and R. Cummings. 2007. Agricultural diversification in South Asia: beyond food security. Pages 47-81 in P. K. Joshi, A. Gulati, and R. Cummings, editors. Agricultural diversification and smallholders in South Asia. Academic Foundation, New Delhi, India.

Junquera, V., and A. Grêt-Regamey. 2019. Crop booms at the forest frontier: triggers, reinforcing dynamics, and the diffusion of knowledge and norms. Global Environmental Change 57:101929. https://doi.org/10.1016/j.gloenvcha.2019.101929

Junquera, V., P. Meyfroidt, Z. Sun, P. Latthachack, and A. GrêtRegamey. 2020. From global drivers to local land-use change: understanding the northern Laos rubber boom. Environmental Science and Policy 109:103-115. https://doi.org/10.1016/j. envsci.2020.04.013

Just, R. E., and Q. Weninger. 1999. Are crop yields normally distributed? American Journal of Agricultural Economics 81:287-304. https://doi.org/10.2307/1244582

Kamanou, G., and J. Morduch. 2002. Measuring vulnerability to poverty. UNU-WIDER, Helsinki, Finland.

Kelly, R. A., A. J. Jakeman, O. Barreteau, M. E. Borsuk, S. ElSawah, S. H. Hamilton, H. J. Henriksen, S. Kuikka, H. R. Maier, A. E. Rizzoli, H. van Delden, and A. A. Voinov. 2013. Selecting among five common modelling approaches for integrated environmental assessment and management. Environmental Modelling and Software 47:159-181. https://doi. org/10.1016/j.envsoft.2013.05.005

Kenney-Lazar, M. 2012. Plantation rubber, land grabbing and social-property transformation in southern Laos. Journal of Peasant Studies 39(3-4):1017-1037. https://doi.org/10.1080/0306$\underline{6150.2012 .674942}$

Kjaerulff, U. B., and A. L. Madsen. 2013. Bayesian networks and influence diagrams: a guide to construction and analysis. Springer, New York, USA. https://doi.org/10.1007/978-1-4614-5104-4

Kronenburg García, A., and H. van Dijk. 2019. Towards a theory of claim making: bridging access and property theory. Society and Natural Resources 33(2):167-183. https://doi. org/10.1080/08941920.2018.1559381

Lade, S. J., L. J. Haider, G. Engström, and M. Schlüter. 2017. Resilience offers escape from trapped thinking on poverty alleviation. Science Advances 3(5):e1603043. https://doi. org/10.1126/sciadv.1603043

Lin, B. B. 2011. Resilience in agriculture through crop diversification: adaptive management for environmental change. BioScience 61(3):183-193. https://doi.org/10.1525/bio.2011.61.3.4

Liu, Y., and H. Man. 2005. Network vulnerability assessment using Bayesian networks. In B. V. Dasarathy, editor. SPIE Proceedings Vol. 5812, Data Mining, Intrusion Detection, Information Assurance, and Data Networks Security. SPIE, Bellingham, Washington, USA. https://doi.org/10.1117/12.604240

Llopis, J. C., C. L. Diebold, F. Schneider, P. C. Harimalala, P. Laby, P. Messerli, and J. G. Zaehringer. 2020. Capabilities under telecoupling: human well-being between cash crops and protected areas in north-eastern Madagascar. Frontiers in Sustainable Food Systems 3(126):1-20. https://doi.org/10.3389/fsufs.2019.00126

Loening, J. L. 2011. Lao People's Democratic Republic: responding to rice price inflation. The World Bank, Washington, D.C., USA. https://doi.org/10.1596/26720

Long, N. 1997. Agency and constraint, perceptions and practice. A theoretical position. Pages 1-20 in H. de Haan and N. Long, editors. Images and realities of rural life. Wageningen perspectives on rural transformations. Van Gorcum, Assen, The Netherlands.

Luers, A. L., D. B. Lobell, L. S. Sklar, C. L. Addams, and P. A. Matson. 2003. A method for quantifying vulnerability, applied to the agricultural system of the Yaqui Valley, Mexico. Global Environmental Change 13(4):255-267. https://doi.org/10.1016/ S0959-3780(03)00054-2

Maity, R., A. Sharma, D. Nagesh Kumar, and K. Chanda. 2013. Characterizing drought using the reliability-resilience-vulnerability concept. Journal of Hydrologic Engineering 18(7):859-869. https:// doi.org/10.1061/(ASCE)HE.1943-5584.0000639

Manivong, V., and R. A. Cramb. 2008. Economics of smallholder rubber expansion in northern Laos. Agroforestry Systems 74:113. https://doi.org/10.1007/s10457-008-9136-3

Marcot, B. G. 2012. Metrics for evaluating performance and uncertainty of Bayesian network models. Ecological Modelling 230:50-62. https://doi.org/10.1016/j.ecolmodel.2012.01.013

Marcot, B. G., J. D. Steventon, G. D. Sutherland, and R. K. McCann. 2006. Guidelines for developing and updating Bayesian belief networks applied to ecological modeling and conservation. Canadian Journal of Forest Research 36(12):3063-3074. https:// doi.org/10.1139/x06-135

Martin, S. M., and K. Lorenzen. 2016. Livelihood diversification in rural Laos. World Development 83:231-243. https://doi. org/10.1016/j.worlddev.2016.01.018

Meyfroidt, P., T. P. Vu, and V. A. Hoang. 2013. Trajectories of deforestation, coffee expansion and displacement of shifting cultivation in the Central Highlands of Vietnam. Global Environmental Change 23(5):1187-1198. https://doi.org/10.1016/ j.gloenvcha.2013.04.005

Morton, J. F. 2007. The impact of climate change on smallholder and subsistence agriculture. Proceedings of the National Academy 
of Sciences 104(50):19680-19685. https://doi.org/10.1073/ pnas.0701855104

Netica. 2019. 3.2 Defining probability tables by equation. https:// www.norsys.com/tutorials/netica/secB/tut B3.htm

Nielson, B. G., and R. DesRoches. 2007. Analytical seismic fragility curves for typical highway bridge classes in the central and southeastern United States. Earthquake Spectra 23(3):615. https://doi.org/10.1193/1.2756815

Nolan, E. 2016. An empirical analysis of market integration for seven food markets in Lao PDR. Food Security in the Northern Uplands Discussion Paper 3. Monash University, Melbourne, Australia.

Ornetsmüller, C., J.-C. Castella, and P. H. Verburg. 2018. A multiscale gaming approach to understand farmer's decision making in the boom of maize cultivation in Laos. Ecology and Society 23(2):35. https://doi.org/10.5751/es-10104-230235

Pacheco, P. 2012. Actor and frontier types in the Brazilian Amazon: assessing interactions and outcomes associated with frontier expansion. Geoforum 43(4):864-874. https://doi. org/10.1016/j.geoforum.2012.02.003

Pingali, P. 2010. Chapter 74 - Agriculture renaissance: making "agriculture for development" work in the 21st century. Pages 3867-3894 in P. Pingali and R. Evenson, editors. Handbook of agricultural economics. Volume 4. Elsevier, Amsterdam, The Netherlands. https://doi.org/10.1016/s1574-0072(09)04074-2

Pingali, P., Y. Khwaja, and M. Meijer. 2005. Commercializing small farms: reducing transaction costs. ESA Working Paper No. 05-08. Food and Agriculture Organization, Rome, Italy.

Pingali, P. L., and M. W. Rosegrant. 1995. Agricultural commercialization and diversification: processes and policies. Food Policy 20(3):171-185. https://doi.org/10.1016/0306-9192(95) 00012-4

Podobnik, B., and H. E. Stanley. 2008. Detrended crosscorrelation analysis: a new method for analyzing two nonstationary time series. Physical Review Letters 100:084102. https://doi.org/10.1103/PhysRevLett.100.084102

Quandl. 2019. Shanghai natural rubber futures, continuous contract \#1 (RU1) (front month). Quandl, Toronto, Ontario, Canada. [online] URL: https://www.quandl.com/data/CHRIS/ SHFE RU1-Shanghai-Natural-Rubber-Futures-Continuous-Contract-1RU1-Front-Month

Quiroz, J. A., and A. Valdés. 1995. Agricultural diversification and policy reform. Food Policy 20(3):245-255. https://doi. org/10.1016/0306-9192(95)00016-8

R Core Team. 2019. R: A language and environment for statistical computing. R Foundation for Statistical Computing, Vienna, Austria.

Reardon, T., K. Stamoulis, and P. Pingali. 2007. Rural nonfarm employment in developing countries in an era of globalization. Agricultural Economics 37(S1):173-183. https://doi.org/10.1111/ j.1574-0862.2007.00243.X

Ribot, J. C., and N. L. Peluso. 2003. A theory of access. Rural Sociology 68(2):153-181. https://doi.org/10.1111/j.1549-0831.2003. tb00133.x
Rigg, J. 2005. Poverty and livelihoods after full-time farming: a South-East Asian view. Asia Pacific Viewpoint 46(2):173-184. https://doi.org/10.1111/j.1467-8373.2005.00266.x

Rigg, J. 2006. Land, farming, livelihoods, and poverty: rethinking the links in the rural South. World Development 34(1):180-202. https://doi.org/10.1016/j.worlddev.2005.07.015

Rigg, J., K. J. Oven, G. Krishna, and R. Lamichhane. 2016. Between a rock and a hard place: vulnerability and precarity in rural Nepal. Geoforum 76:63-74. https://doi.org/10.1016/j. geoforum.2016.08.014

Rousseau, J.-F., and J. Sturgeon. 2019. The disappearance of water buffalo from agrarian landscapes in Western China. Journal of Agrarian Change 19(2):319-336. https://doi.org/10.1111/ joac. 12289

Rousseau, J.-F., S. Turner, and Y. Xu. 2019. Cardamom casualties: extreme weather events and ethnic minority livelihood vulnerability in the Sino-Vietnamese borderlands. Climate 7 (1):14. https://doi.org/10.3390/cli7010014

Russell, A. J. M., J. Foppes, D. C. Behr, S. Ketphanh, and S. Rafanoharana. 2015. Using forests to enhance resilience to climate change: the case of smallholder agriculture in Savannakhet Province in Lao PDR. Program on Forests, Washington, D.C., USA. [online] URL: https://www.cifor.org/publications/pdf_files/ Papers/PRussell1501.pdf

Scoones, I. 1998. Sustainable rural livelihoods: a framework for analysis. IDS Working Paper 72. Institute of Development Studies, Brighton, UK.

Scoones, I. 2009. Livelihoods perspectives and rural development. Journal of Peasant Studies 36(1):171-196. https://doi. org/10.1080/03066150902820503

Sen, A. K. 1984. Resources, values and development. Blackwell, Oxford, UK.

Siegel, P. B. 2008. Profile of Zambia's smallholders: Where and Who are the potential beneficiaries of agricultural commercialization? Africa Region Working Paper Series No. 113. The World Bank, Washington, D.C., USA. [online] URL: https://documents. worldbank.org/pt/publication/documents-reports/ documentdetail/866191468179962814/profile-of-zambias-smallholderswhere-and-who-are-the-potential-beneficiaries-of-agriculturalcommercialization

Steiger, S. G. 2019. Spatio-temporal ecosystem service assessment in Luang Namtha Province, Northern Laos. University of Bern, Bern, Switzerland.

Stokely, M. 2015. Package HistogramTools, Utility Functions for $R$ Histograms.

Stritih, A., P. Bebi, and A. Grêt-Regamey. 2019. Quantifying uncertainties in earth observation-based ecosystem service assessments. Environmental Modelling \& Software 111:300-310. https://doi.org/10.1016/j.envsoft.2018.09.005

Sturgeon, J. C. 2013. Cross-border rubber cultivation between China and Laos: regionalization by Akha and Tai rubber farmers. Singapore Journal of Tropical Geography 34(1):70-85. https://doi. org/10.1111/sjtg. 12014 
United Nations Development Programme (UNDP). 2001. National human development report Lao PDR 2001. UNDP, New York, New York, USA.

Upadhyay, B. M., and E. G. Smith. 2005. Modeling crop yield distributions from small samples. Proceeding of the Canadian Agricultural Economics Society (CAES) Annual Meeting, San Francisco, California, July 6-8. [online] URL: https:// d1rkab7tlqy5f1.cloudfront.net/TBM/Over\%20faculteit/Afdelingen/ Values $\% 2 \mathrm{C} \% 20$ Technology $\% 20$ and $\% 20$ Innovation/People/Full $\%$ 20Professors/Pieter\%20van $\% 20$ Gelder/Citations/citatie sp05up 01. pdf

Uusitalo, L. 2007. Advantages and challenges of Bayesian networks in environmental modelling. Ecological Modelling 203 (3-4):312-318. https://doi.org/10.1016/j.ecolmodel.2006.11.033

van Vliet, N., C. Adams, I. C. Guimarães Vieira, and O. Mertz. 2013. "Slash and burn" and "shifting" cultivation systems in forest agriculture frontiers from the Brazilian Amazon. Society and Natural Resources 26(12):1454-1467. https://doi. org/10.1080/08941920.2013.820813

van Vliet, N., O. Mertz, A. Heinimann, T. Langanke, U. Pascual, B. Schmook, C. Adams, D. Schmidt-Vogt, P. Messerli, S. Leisz, J. C. Castella, L. Jørgensen, T. Birch-Thomsen, C. Hett, T. B. Bruun, A. Ickowitz, K. C. Vu, K. Yasuyuki, J. Fox, C. Padoch, W. Dressler, and A. D. Ziegler. 2012. Trends, drivers and impacts of changes in swidden cultivation in tropical forest-agriculture frontiers: a global assessment. Global Environmental Change 22 (2):418-429. https://doi.org/10.1016/j.gloenvcha.2011.10.009

Vang Rasmussen, L., B. Coolsaet, A. Martin, O. Mertz, U. Pascual, E. Corbera, N. Dawson, J. A. Fisher, P. Franks, and C. M. Ryan. 2018. Social-ecological outcomes of agricultural intensification. Nature Sustainability 1:275-282. https://doi. org/10.1038/s41893-018-0070-8

von Braun, J. 1995. Agricultural commercialization: impacts on income and nutrition and implications for policy. Food Policy 20 (3):187-202. https://doi.org/10.1016/0306-9192(95)00013-5

Vongvisouk, T., and M. Dwyer. 2017. After the boom: responding to falling rubber prices in northern Laos. Mekong Region Land Governance Project, Vientiane Lao PDR and Forest Trends, Washington, D.C., USA.

Wagstaff, A., and M. Lindelow. 2014. Are health shocks different? Evidence from a multishock survey in Laos. Health Economics 23 (6):706-718. https://doi.org/10.1002/hec.2944

Walker, B., L. Pearson, M. Harris, K. G. Maler, C. Z. Li, R. Biggs, and T. Baynes. 2010. Incorporating resilience in the assessment of inclusive wealth: an example from South East Australia. Environmental and Resource Economics 45(2):183-202. https:// doi.org/10.1007/s10640-009-9311-7

Wood, B., C. Nelson, T. Kilic, and S. Murray. 2013. Up in Smoke? Agricultural commercialization, rising food prices and stunting in Malawi. The World Bank, Washington, D.C., USA. https://doi. org/10.1596/1813-9450-6650

Yilma, Z., A. Mebratie, R. Sparrow, D. Abebaw, M. Dekker, G. Alemu, and A. S. Bedi. 2014. Coping with shocks in rural
Ethiopia. Journal of Development Studies 50(7):1009-1024. https://doi.org/10.1080/00220388.2014.909028

Zaehringer, J. G., L. Lundsgaard-Hansen, T. T. Thein, J. C. Llopis, N. N. Tun, W. Myint, and F. Schneider. 2020. The cash crop boom in southern Myanmar: tracing land use regime shifts through participatory mapping. Ecosystems and People 16(1):36-49. https://doi.org/10.1080/26395916.2019.1699164

Zuo, Z., J. C. Langill, S. Turner, and J. F. Rousseau. 2020. Spices as the saviour? The complex vulnerabilities of three commodity crop booms and ethnic minority livelihoods in Yunnan's agrarian frontier. Asia Pacific Viewpoint. https://doi.org/10.1111/ apv. 12291 
Appendix 1/10

\section{Tables}

Table A1.1: Summary of household-level statistics (mean and standard deviation) for each case study area (CSA). The values reflect conditions in December 2017 unless otherwise noted.

\begin{tabular}{|c|c|c|c|}
\hline Household variable & $\begin{array}{l}\text { Oudomsin CSA } \\
\qquad(\mathrm{N}=60)\end{array}$ & $\begin{array}{l}\text { Prang CSA } \\
(\mathrm{N}=50)\end{array}$ & $\begin{array}{l}\text { Wilcoxon p- } \\
\text { value* }\end{array}$ \\
\hline Age of head of the household & $45(11)$ & $49(13)$ & \\
\hline Number of persons (count) & $6.7(2.6)$ & $5.5(2.2)$ & $* * *$ \\
\hline Number of labor (count) & $3.2(1.3)$ & $2.2(0.8)$ & $* * *$ \\
\hline $\begin{array}{l}\text { Education of head of the household }(0=\text { none, } 1=\text { primary school, } 2= \\
\text { secondary school, } 3=\text { high school or higher })\end{array}$ & $0.9(0.8)$ & $1.1(0.7)$ & $*$ \\
\hline Year the household was established in the village & $1990(10)$ & $1990(9)$ & \\
\hline Average distance to all household plots, minutes & $17(13)$ & $20(14)$ & \\
\hline Average distance to all household plots, kilometers & $1.6(1.0)$ & $1.4(0.7)$ & \\
\hline Total income (1000 USD) & $4.0(3.5)$ & $1.2(1.0)$ & $* * *$ \\
\hline Income from agricultural wages (1000 USD) & $1.0(1.9)$ & $0.1(0.2)$ & $* * *$ \\
\hline Income from agricultural production (without wages) (1000 USD) & $2.3(2.3)$ & $0.9(0.8)$ & $* * *$ \\
\hline Net rice income $\ddagger$ (1000 USD) & $0.8(0.8)$ & $0.7(0.4)$ & \\
\hline Income from remittances (1000 USD) & $0.002(0.01)$ & $0.03(0.2)$ & \\
\hline Other nonagricultural income (1000 USD) & $0.6(1.3)$ & $0.03(0.2)$ & $* * *$ \\
\hline Income in 2005 (1000 USD) & $1.9(1.2)$ & $0.4(0.4)$ & $* * *$ \\
\hline Labor in 2005 (count) & $2.7(1.3)$ & $2.2(1.0)$ & $* *$ \\
\hline Total agricultural area (ha) & $5.6(2.8)$ & $2.9(1.2)$ & $* * *$ \\
\hline Rubber area (ha) & $4.0(2.2)$ & $1.1(0.8)$ & $* * *$ \\
\hline Cardamom area (ha) & $0.07(0.2)$ & $0.4(0.4)$ & $* * *$ \\
\hline Rice paddy area (ha) & $0.6(0.6)$ & $0.5(0.3)$ & \\
\hline Paddy land under banana (ha) & $0.0(0.2)$ & 0 & \\
\hline Paddy land under sugarcane (ha) & $0.9(1.0)$ & 0 & $* * *$ \\
\hline Upland rice area (ha) & $0.03(0.1)$ & $0.5(0.8)$ & $* * *$ \\
\hline Total rice production (metric tons) & $2.7(2.3)$ & $2.3(1.2)$ & \\
\hline Paddy rice production (metric tons) & $1.9(2.0)$ & $1.7(1.3)$ & \\
\hline Upland rice production (metric tons) & $0.1(0.3)$ & $0.6(0.8)$ & $* * *$ \\
\hline Other upland rice production (metric tons) & $0.3(0.7)$ & 0 & $* * *$ \\
\hline Rice sold (metric tons) & $0.7(1.5)$ & $0.0(0.1)$ & \\
\hline Rice purchased (metric tons) & $0.2(0.5)$ & $0.0(0.2)$ & \\
\hline Rubber yield (ton/ha) & $1.4(1.0)$ & $1.4(0.7)$ & \\
\hline Paddy rice yield (ton/ha) & $3.6(1.6)$ & $3.8(1.3)$ & \\
\hline Upland rice yield (ton/ha) & $1.6(0.4)$ & $1.3(0.7)$ & \\
\hline Cardamom yield (ton/ha) & na & $0.9(0.3)$ & nd \\
\hline Rubber farm-gate price (USD/kg) & $0.7(0.1)$ & $0.7(0.1)$ & \\
\hline Rice price, nonhulled, farm-gate (USD/kg) & $0.3(0.02)$ & $0.3(0.03)$ & \\
\hline Cardamom price (USD/kg) & $0.7(0.6)$ & $0.9(1.0)$ & \\
\hline Rubber revenue $^{\dagger}(1000$ USD/ha) & $1.7(1.6)$ & $0.2(0.2)$ & nd \\
\hline Fraction of rubber revenue over total household income $^{\dagger}$ & $0.4(0.3)$ & $0.4(0.3)$ & nd \\
\hline Cardamom revenue $^{\dagger}(1000 \mathrm{USD} / \mathrm{ha})$ & $0.5(0.4)$ & $0.3(0.2)$ & nd \\
\hline Fraction of cardamom revenue over total household income ${ }^{\dagger}$ & $0.1(0.1)$ & $0.5(0.3)$ & nd \\
\hline Paddy lease revenue (1000 USD/ha) ${ }^{\dagger \dagger}$ & $1.3(0.9)$ & na & nd \\
\hline Fraction of paddy lease revenue over total household income ${ }^{\dagger \dagger}$ & $0.3(0.3)$ & na & nd \\
\hline Paddy rice revenue $(1000 \mathrm{USD} / \mathrm{ha})^{\sharp}$ & $1.1(0.4)$ & $1.1(0.3)$ & nd \\
\hline \multicolumn{4}{|c|}{ 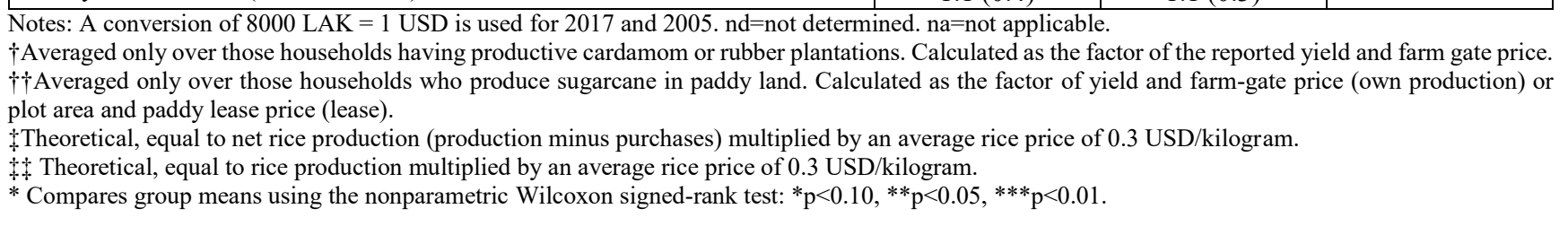 } \\
\hline
\end{tabular}

Junquera, V. and Grêt-Regamey, A. Assessing livelihood vulnerability using a Bayesian network: a case study in northern Laos. 
Appendix 2/10

Table A1.2: Description of the variables in the BN and parameterization

\begin{tabular}{|c|c|c|c|c|c|c|c|}
\hline $\begin{array}{l}\text { Variable name in } \\
\text { BN }\end{array}$ & Description & Unit & $\begin{array}{l}\text { Type } \\
\text { and } \\
\text { subtype }\end{array}$ & Parameterization & Scale & $\begin{array}{l}\text { Temporal } \\
\text { range of } \\
\text { the data }\end{array}$ & $\begin{array}{l}\text { Mean } \\
(\mathrm{SD}) \dagger\end{array}$ \\
\hline CSA & Case study area & NA & $\mathrm{D}, \mathrm{L}$ & $\mathrm{S}$ & $\mathrm{CSA}$ & NA & - \\
\hline $\mathrm{HHaP}$ & HH ha of paddy rice & ha & $\mathrm{C}, \mathrm{I}$ & $\mathrm{S}$ & $\mathrm{H}$ & 2017 & $\begin{array}{l}0.6 \\
(0.6)\end{array}$ \\
\hline HHaUR & $\begin{array}{l}\mathrm{HH} \text { ha of upland } \\
\text { rice }\end{array}$ & ha & $\mathrm{C}, \mathrm{I}$ & $\mathrm{S}$ & $\mathrm{H}$ & 2017 & $\begin{array}{l}0.4 \\
(0.8)\end{array}$ \\
\hline HHaLeaseP & $\begin{array}{l}\text { HH ha of leased } \\
\text { paddy }\end{array}$ & ha & $\mathrm{C}, \mathrm{I}$ & $\mathrm{S}$ & $\mathrm{H}$ & 2017 & $\begin{array}{l}0.9 \\
(1.1)\end{array}$ \\
\hline $\mathrm{HHaR}$ & HH ha of rubber & ha & $\mathrm{C}, \mathrm{I}$ & $\mathrm{S}$ & $\mathrm{H}$ & 2017 & $\begin{array}{l}2.8 \\
(2.4)\end{array}$ \\
\hline $\mathrm{HHaC}$ & $\begin{array}{l}\text { HH ha of } \\
\text { cardamom }\end{array}$ & ha & $\mathrm{C}, \mathrm{I}$ & $\mathrm{S}$ & $\mathrm{H}$ & 2017 & $\begin{array}{l}0.3 \\
(0.5)\end{array}$ \\
\hline Yield_P_obs & $\begin{array}{l}\text { Yield, paddy rice } \\
\text { (observed) }\end{array}$ & ton $/ \mathrm{ha} / \mathrm{yr}$ & $\mathrm{C}, \mathrm{I}$ & $\mathrm{S}$ & $\mathrm{P}$ & $\begin{array}{l}1990- \\
2017\end{array}$ & $\begin{array}{l}3.6 \\
(1.3)\end{array}$ \\
\hline Yield_P & Yield, paddy rice & ton $/ \mathrm{ha} / \mathrm{yr}$ & $\mathrm{C}, \mathrm{I}$ & $\begin{array}{l}\mathrm{P}(\text { Yield_P } \mid \text { Yield_P_obs })= \\
\text { NormalDist(Yield_P, Yield_P_obs,SD }= \\
0.34)\end{array}$ & $\mathrm{P}$ & $\begin{array}{l}1990- \\
2017\end{array}$ & $\begin{array}{l}3.6 \\
(1.3)\end{array}$ \\
\hline Yield_UR_obs & $\begin{array}{l}\text { Yield, upland rice } \\
\text { (observed) }\end{array}$ & ton $/ \mathrm{ha} / \mathrm{yr}$ & $\mathrm{C}, \mathrm{I}$ & $\mathrm{S}$ & $\mathrm{P}$ & $\begin{array}{l}1990- \\
2017\end{array}$ & $\begin{array}{l}1.3 \\
(0.8)\end{array}$ \\
\hline Yield_UR & Yield, upland rice & ton $/ \mathrm{ha} / \mathrm{yr}$ & $\mathrm{C}, \mathrm{I}$ & $\begin{array}{l}\text { P(Yield_UR/Yield_UR_obs) }= \\
\text { NormalDist(Yield_UR, Yield_UR_obs, } \\
\text { SD }=0.20)\end{array}$ & $\mathrm{P}$ & $\begin{array}{l}1990- \\
2017\end{array}$ & $\begin{array}{l}1.3 \\
(0.8)\end{array}$ \\
\hline Yield_R & Yield, rubber & ton $/ \mathrm{ha} / \mathrm{yr}$ & $\mathrm{C}, \mathrm{I}$ & $\mathrm{S}$ & $\mathrm{P}$ & 2017 & $\begin{array}{l}1.3 \\
(0.8)\end{array}$ \\
\hline Yield_C & Yield, cardamom & ton $/ \mathrm{ha} / \mathrm{yr}$ & $\mathrm{C}, \mathrm{I}$ & $\mathrm{S}$ & $\mathrm{P}$ & 2017 & $\begin{array}{l}0.9 \\
(0.3)\end{array}$ \\
\hline UR_HH_Kg & $\begin{array}{l}\text { HH production of } \\
\text { upland rice }\end{array}$ & ton $/ \mathrm{yr}$ & $\mathrm{C}, \mathrm{I}$ & $\begin{array}{l}\text { UR_HH_Kg }=\text { UR_Oth_HH_Kg + } \\
\text { HHaUR * Yield_UR }\end{array}$ & $\mathrm{H}$ & 2017 & $\begin{array}{l}0.8 \\
(1.4)\end{array}$ \\
\hline UR_Oth_HH_Kg & $\begin{array}{l}\text { Other HH upland } \\
\text { rice production }\end{array}$ & ton $/ \mathrm{yr}$ & $\mathrm{C}, \mathrm{I}$ & $\mathrm{S}$ & $\mathrm{H}$ & 2017 & $\begin{array}{l}0.3 \\
(0.7)\end{array}$ \\
\hline P_HH_Kg & $\begin{array}{l}\text { HH production of } \\
\text { paddy rice }\end{array}$ & ton $/ \mathrm{yr}$ & $\mathrm{C}, \mathrm{I}$ & P_HH_Kg $=\mathrm{HHaP} *$ Yield_P & $\mathrm{H}$ & 2017 & $\begin{array}{l}2.1 \\
(2.2)\end{array}$ \\
\hline Price_Rice_Local & $\begin{array}{l}\text { Price of rice } \\
\text { (unhulled), local }\end{array}$ & $\mathrm{USD} / \mathrm{kg}^{*}$ & $\mathrm{C}, \mathrm{I}$ & $\begin{array}{l}\text { P }(\text { Price_Rice_Local } \mid \text { Price_Rice_Market) } \\
=\text { NormalDist }(\text { mean }= \\
\text { Price_Rice_Market*1.46e-3, SD }=0.027)\end{array}$ & $\mathrm{P}$ & $\begin{array}{l}2000- \\
2017\end{array}$ & $\begin{array}{l}0.2 \\
(0.1)\end{array}$ \\
\hline Price_Rice_Market & $\begin{array}{l}\text { Price of rice } \\
\text { (unhulled), market }\end{array}$ & USD $/ \mathrm{kg}^{*}$ & $\mathrm{C}, \mathrm{I}$ & $\begin{array}{l}\text { Frequency count of annual averages, } \\
\text { FAOSTAT }(2020)\end{array}$ & CSA & $\begin{array}{l}2000- \\
2016\end{array}$ & $\begin{array}{l}140 \\
(48)\end{array}$ \\
\hline Price_R & $\begin{array}{l}\text { Price of rubber } \\
\text { latex, local }\end{array}$ & $\begin{array}{l}\text { USD/kg- } \\
\text { wet* }\end{array}$ & $\mathrm{C}, \mathrm{I}$ & $\begin{array}{l}\text { P }(\text { Price_R } \mid \text { Price_R_CHN })=\text { NormalDist } \\
(\text { mean }=\text { Price R } \mathrm{CHN} * 0.42, \mathrm{SD}=0.11)\end{array}$ & $\mathrm{P}$ & $\begin{array}{l}2003- \\
2017\end{array}$ & $\begin{array}{l}1.1 \\
(0.5)\end{array}$ \\
\hline Price_R_CHN & $\begin{array}{l}\text { Price of rubber } \\
\text { latex (raw), China }\end{array}$ & $\begin{array}{l}\text { USD/kg- } \\
\text { dry* }\end{array}$ & $\mathrm{C}, \mathrm{I}$ & $\begin{array}{l}\text { Frequency count of annual averages, } \\
\text { Indexmundi (2019) }\end{array}$ & CSA & $\begin{array}{l}1995- \\
2017\end{array}$ & $\begin{array}{l}2.4 \\
(1.2)\end{array}$ \\
\hline Price_C & $\begin{array}{l}\text { Price of cardamom } \\
\text { (with hull) }\end{array}$ & $\mathrm{USD} / \mathrm{kg}$ & $\mathrm{C}, \mathrm{I}$ & $\mathrm{S}$ & $\mathrm{P}$ & $\begin{array}{l}2007- \\
2017\end{array}$ & $\begin{array}{l}0.8 \\
(0.1)\end{array}$ \\
\hline Price_LeaseP & Price of paddy lease & $\mathrm{USD} / \mathrm{ha} / \mathrm{yr}$ & $\mathrm{C}, \mathrm{I}$ & 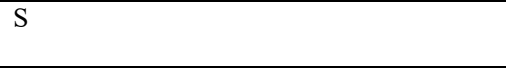 & $\mathrm{P}$ & $\begin{array}{l}2011- \\
2017\end{array}$ & $\begin{array}{l}984 \\
(670)\end{array}$ \\
\hline R_HH_Inc & $\begin{array}{l}\text { HH income from } \\
\text { rubber latex }\end{array}$ & $\mathrm{USD} / \mathrm{yr}$ & $\mathrm{C}, \mathrm{I}$ & $\begin{array}{l}\mathrm{R} \_\mathrm{HH} \_ \text {Inc }=\text { Yield_R } * \text { Price_R } * \mathrm{HHaR} * \\
1000\end{array}$ & $\mathrm{H}$ & 2017 & $\begin{array}{l}3940 \\
(5500)\end{array}$ \\
\hline C_HH_Inc & $\begin{array}{l}\text { HH income from } \\
\text { cardamom }\end{array}$ & USD/yr & $\mathrm{C}, \mathrm{I}$ & $\begin{array}{l}\text { C_HH_Inc }=\text { Yield_C } * \text { Price_C } * \\
\mathrm{HH}_{-} \mathrm{C}^{*} 1000\end{array}$ & $\mathrm{H}$ & 2017 & $\begin{array}{l}261 \\
(490)\end{array}$ \\
\hline LeaseP_HH_Inc & $\begin{array}{l}\text { HH income from } \\
\text { leased paddy }\end{array}$ & $\mathrm{USD} / \mathrm{yr}$ & $\mathrm{C}, \mathrm{I}$ & $\begin{array}{l}\text { LeaseP_HH_Inc }=\text { Price_LeaseP } * \\
\text { HHaLeaseP }\end{array}$ & $\mathrm{H}$ & 2017 & $\begin{array}{l}854 \\
(1500)\end{array}$ \\
\hline Total_HH_Ag_Inc & $\begin{array}{l}\text { HH revenue from } \\
\text { cash crops }\end{array}$ & $\mathrm{USD} / \mathrm{yr}$ & $\mathrm{C}, \mathrm{I}$ & $\begin{array}{l}\text { Total_HH_Ag_Inc }=\text { R_HH_Inc }+ \\
\text { LeaseP_HH_Inc }+\mathrm{C} \text { HH Inc }\end{array}$ & $\mathrm{H}$ & 2017 & $\begin{array}{l}5060 \\
(5800)\end{array}$ \\
\hline HHPers & $\begin{array}{l}\text { Number of persons } \\
\text { in the HH }\end{array}$ & count & $\mathrm{D}, \mathrm{N}$ & $\mathrm{S}$ & $\mathrm{H}$ & 2017 & $\begin{array}{l}6.9 \\
(3.4)\end{array}$ \\
\hline HHRice_cons & $\begin{array}{l}\text { HH rice } \\
\text { consumption }\end{array}$ & $\mathrm{kg} / \mathrm{yr}$ & $\mathrm{C}, \mathrm{I}$ & HHRice_cons $=1.11+$ HHPers $* 0.185$ & $\mathrm{H}$ & 2017 & $\begin{array}{l}2.4 \\
(0.7)\end{array}$ \\
\hline Net_Rice_Prod & $\begin{array}{l}\text { HH net rice } \\
\text { production }\end{array}$ & $\mathrm{kg} / \mathrm{yr}$ & $\mathrm{C}, \mathrm{I}$ & $\begin{array}{l}\text { Net_Rice_Prod }=\text { UR_HH_Kg }+ \\
\text { P_HH_Kg - HHRice_cons }\end{array}$ & $\mathrm{H}$ & 2017 & $\begin{array}{l}0.5 \\
(2.7)\end{array}$ \\
\hline Net_Income & $\begin{array}{l}\text { HH net agricultural } \\
\text { production income }\end{array}$ & USD/yr & $\mathrm{C}, \mathrm{I}$ & $\begin{array}{l}\text { Net_Income }=\text { Total_HH_Ag_Inc }+ \\
(\text { Net Rice Prod } * \text { Price Rice } * 1000)\end{array}$ & $\mathrm{H}$ & 2017 & $\begin{array}{l}5160 \\
(5800)\end{array}$ \\
\hline
\end{tabular}

Abbreviations: HH=household; ha=hectares; yr=year. Type=Discrete or Continuous, Subtype=Labeled, Boolean, Numbered, or Interval.

Parameterization=Survey data; other sources or deterministic equations are indicated. Scale=Case Study Area, Household, or Plot.

*USD=US Dollar; CNY=Chinese Yuan; LAK=Lao Kip. Fixed currency conversions corresponding to 2017 levels were used: LAK/USD=8000;

$\mathrm{CNY} / \mathrm{LAK}=1255$.

$\dagger$ Indicates the mean and standard deviation (SD) of the variable calculated by the BN when no nodes are instantiated.

Junquera, V. and Grêt-Regamey, A. Assessing livelihood vulnerability using a Bayesian network: a case study in northern Laos. 
Appendix 3/10

Table A1.3-A: Empirical mean and standard deviation of household variables for households in the lower (0-25\%), medium (25-75\%), and higher (75-100\%) income quantiles based on household survey data.

\begin{tabular}{|l|c|c|c|c|c|c|}
\hline Case Study Area & \multicolumn{3}{|c|}{ Prang } & \multicolumn{3}{c|}{ Oudomsin } \\
\hline Household Income Quantile & $\begin{array}{c}75-100 \% \\
\text { (High- } \\
\text { income) }\end{array}$ & $25-75 \%$ & $\begin{array}{c}0-25 \% \\
\text { (Low- } \\
\text { income) }\end{array}$ & $\begin{array}{c}75-100 \% \\
\text { (High- } \\
\text { income) }\end{array}$ & $\begin{array}{c}25-75 \% \\
(\text { Low- } \\
\text { income) }\end{array}$ \\
\hline $\begin{array}{l}\text { Total income } \\
\text { (1000 USD) }\end{array}$ & $2.3(1.0)$ & $0.98(0.65)$ & $0.48(0.59)$ & $8.0(3.9)$ & $3.4(2.3)$ & $1.1(0.75)$ \\
\hline $\begin{array}{l}\text { Agricultural income (1000 } \\
\text { USD) }\end{array}$ & $1.9(0.80)$ & $0.67(0.28)$ & $0.16(0.08)$ & $5.5(2.1)$ & $1.7(0.69)$ & $0.25(0.23)$ \\
\hline $\begin{array}{l}\text { Rice production per person } \\
\text { ton) }\end{array}$ & $0.43(0.13)$ & $0.42(0.22)$ & $0.47(0.25)$ & $0.54(0.51)$ & $0.43(0.29)$ & $0.25(0.16)$ \\
\hline $\begin{array}{l}\text { Rice purchase per person } \\
\text { ton) }\end{array}$ & 0 & $0.02(0.04)$ & $0.002(0.01)$ & $0.02(0.06)$ & $0.04(0.10)$ & $0.04(0.07)$ \\
\hline Rubber (ha) & $1.56(0.58)$ & $1.2(0.80)$ & $0.61(0.49)$ & $5.9(2.4)$ & $3.7(1.6)$ & $2.6(1.7)$ \\
\hline Paddy (ha) & $0.72(0.26)$ & $0.42(0.24)$ & $0.27(0.26)$ & $0.91(0.4)$ & $0.52(0.7)$ & $0.27(0.5)$ \\
\hline Upland rice (ha) & $0.18(0.41)$ & $0.45(0.75)$ & $1.0(0.97)$ & $0.01(0.05)$ & $0.01(0.04)$ & $0.11(0.22)$ \\
\hline Cardamom (ha) & $0.51(0.58)$ & $0.34(0.25)$ & $0.39(0.50)$ & $0.09(0.13)$ & $0.1(0.22)$ & $0.02(0.04)$ \\
\hline Paddy lease (ha) & 0 & 0 & 0 & $1.2(1.1)$ & $1.1(0.89)$ & $0.31(0.34)$ \\
\hline Household persons & $6.9(2.7)$ & $5.0(2.0)$ & $4.8(1.3)$ & $7.9(2.9)$ & $6.7(2.7)$ & $5.4(1.3)$ \\
\hline
\end{tabular}

Table A1.3-B: Values of household variables instantiated in the BN to represent low-income and high-income households in each case study area. The values correspond to the variable state in the BN that best matches the values in Table A3-A.

\begin{tabular}{|l|c|c|c|c|}
\hline Case Study Area & \multicolumn{2}{|c|}{ Prang } & \multicolumn{2}{c|}{ Oudomsin } \\
\hline & High-income & Low-income & High-income & Low-income \\
\hline HHaR & 1.5 & 0.5 & 5.5 & 2.5 \\
\hline HHaP & 0.75 & 0.25 & 1 & 0.25 \\
\hline HHaUR & 0.125 & 1 & 0 & 0.125 \\
\hline HHaC & 0.5 & 0.5 & 0 & 0 \\
\hline HHaLeaseP & 0 & 0 & 1.25 & 0.25 \\
\hline HHPers & 7 & 5 & 8 & 5 \\
\hline
\end{tabular}

Table A1.3-C: Values of household variables instantiated in the BN to represent low-income and middle-income households across case study areas.

\begin{tabular}{|l|c|c|}
\hline & Middle-income & Low-income \\
\hline $\begin{array}{l}\text { Upland hectares (HHaR, HHaC, HHaUR*, or a mix) } \\
\text { *only for low-income household }\end{array}$ & 4 & 2 \\
\hline Lowland hectares (HHaP or HHaLeaseP) & 1.5 & 0.4 \\
\hline HHPers & 6 & 5 \\
\hline
\end{tabular}

Junquera, V. and Grêt-Regamey, A. Assessing livelihood vulnerability using a Bayesian network: a case study in northern Laos. 
Appendix 4/10

Table A1.4: Household livelihood conceptualization: the sum of a household's material and economic stocks and flows

\begin{tabular}{|c|c|c|c|}
\hline \multicolumn{2}{|c|}{$\begin{array}{l}\text { Household livelihood } \\
\text { components }\end{array}$} & $\begin{array}{c}\text { Livelihood stocks and flows relevant to } \\
\text { the study }\end{array}$ & How it is addressed in the $B N$ model \\
\hline \multirow[t]{4}{*}{ Flows } & \multirow[t]{2}{*}{ Material } & Food production and consumption & $\begin{array}{l}\text { Production and consumption of rice, as the main } \\
\text { household food item, is included in the BN model; it } \\
\text { is converted into net cash flow depending on whether } \\
\text { net household rice production is positive or negative } \\
\text { for the year }\end{array}$ \\
\hline & & $\begin{array}{l}\text { Other household consumption (e.g., } \\
\text { fertilizer, school supplies, etc.), } \\
\text { including regular and unforeseen } \\
\text { expenses (e.g., medical services) }\end{array}$ & Not included in the BN model. \\
\hline & \multirow[t]{2}{*}{ Economic } & Cash income & $\begin{array}{l}\text { Agricultural production income is included in the } \\
\text { model; other income sources are not included. }\end{array}$ \\
\hline & & Cash expenses & $\begin{array}{l}\text { Rice purchases are included in the model (see } \\
\text { material flows); other expenses are not included. }\end{array}$ \\
\hline \multirow[t]{2}{*}{ Stocks } & Material & $\begin{array}{l}\text { Capital assets: house, motorcycles, } \\
\text { tractor, cattle, and so forth }\end{array}$ & Not included in the BN model. \\
\hline & Economic & Cash savings & Not included in the BN model. \\
\hline
\end{tabular}


Appendix 5/10

\section{Figures}

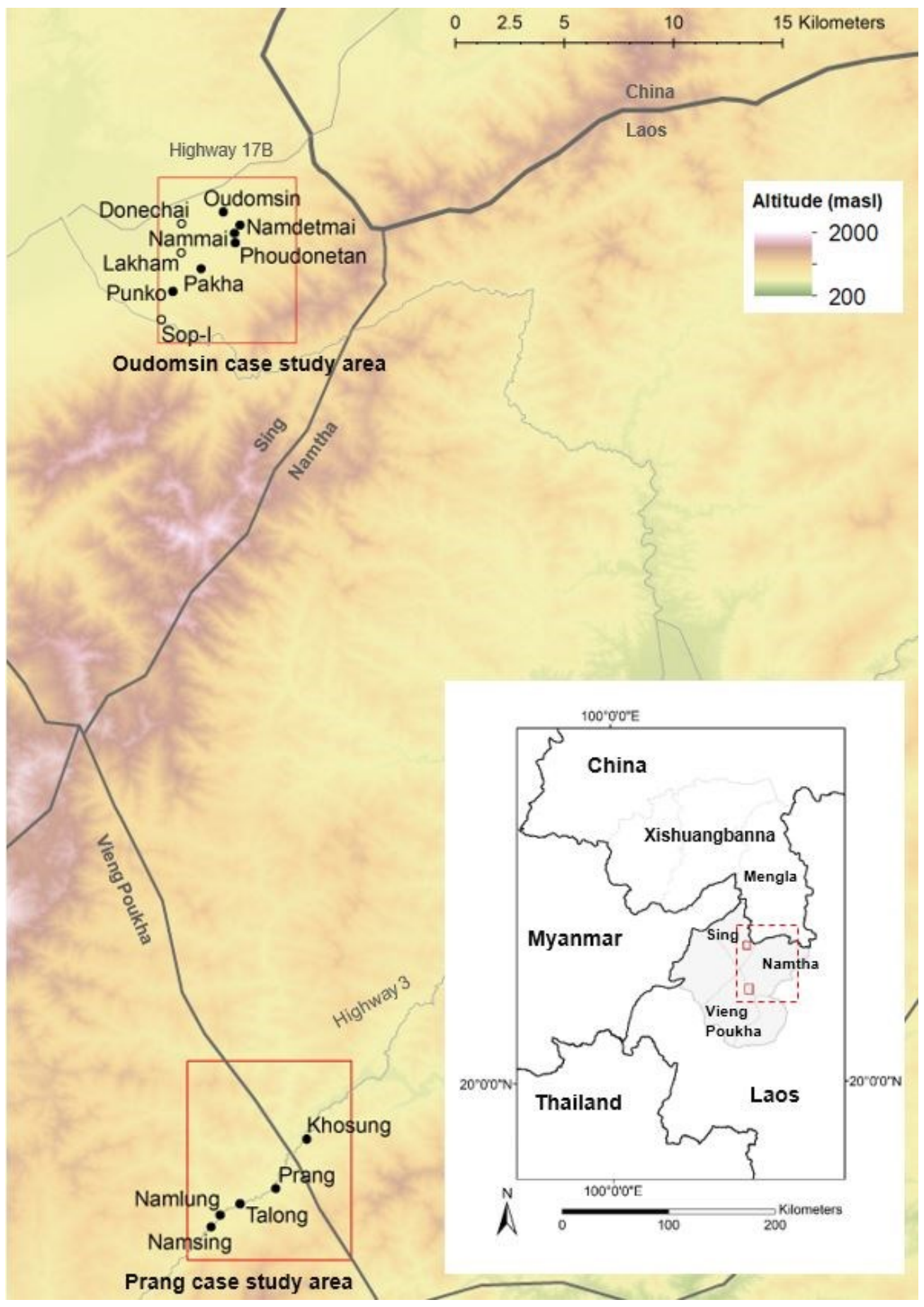

Figure A1.1: Map of the two case study areas and villages studied (solid points). Luang Namtha Province is shaded in gray in the lower map. 
Appendix 6/10

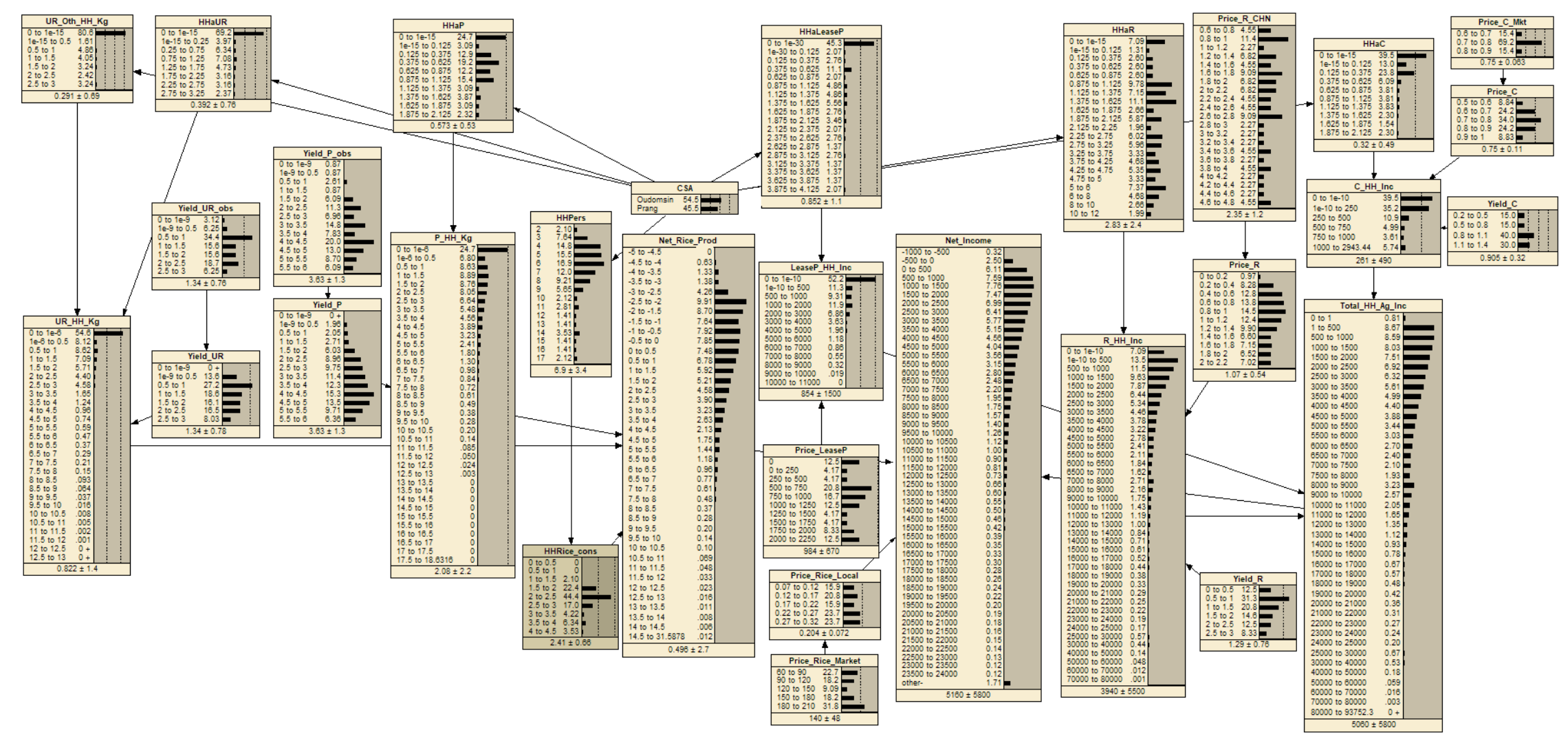

Figure A1.2: Bayesian network model. Details are shown on the next two pages. 
Appendix 7/10

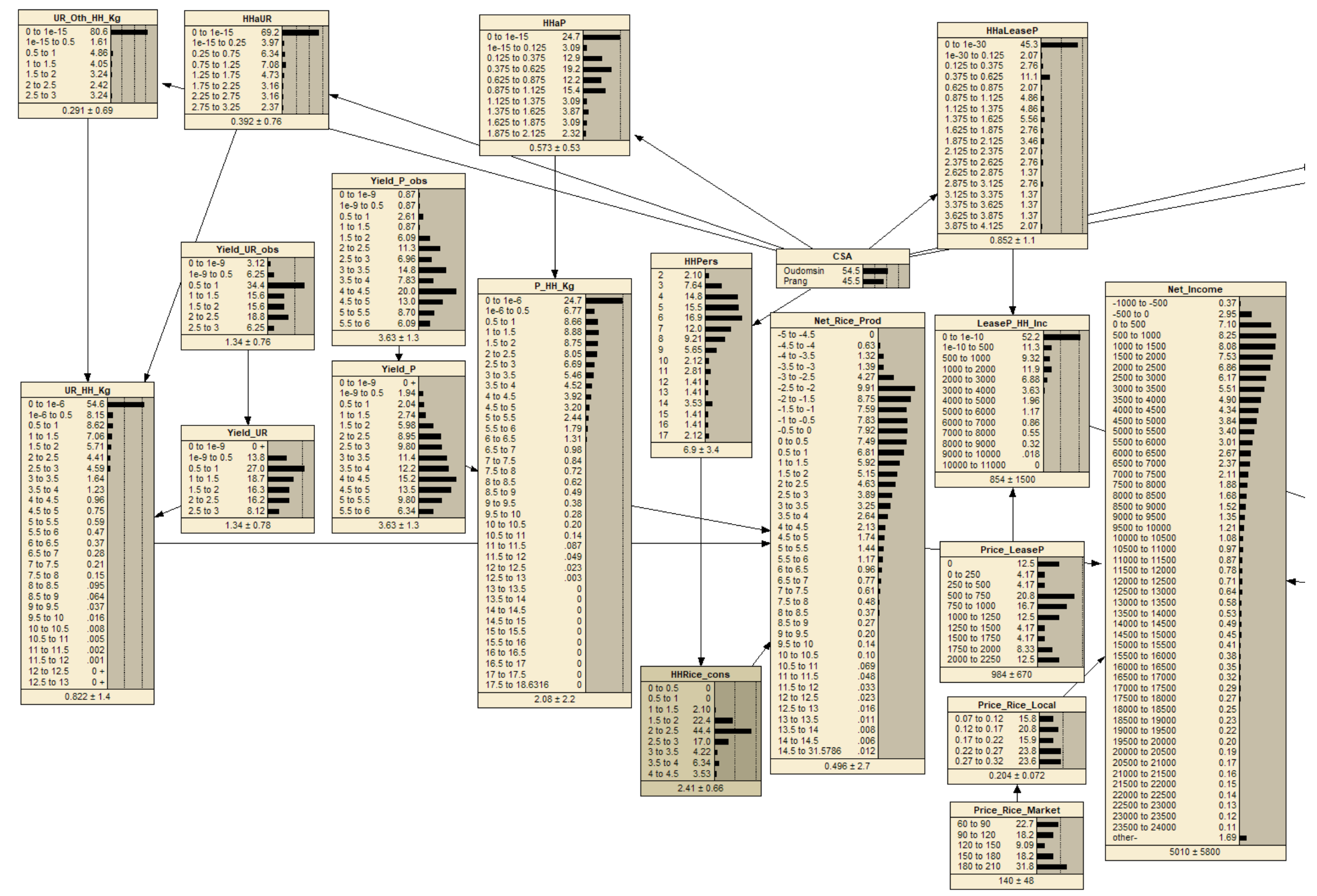

Figure A1.2 (Cont.)

Junquera, V. and Grêt-Regamey, A. Assessing livelihood vulnerability using a Bayesian network: a case study in northern Laos. 
Appendix 8/10

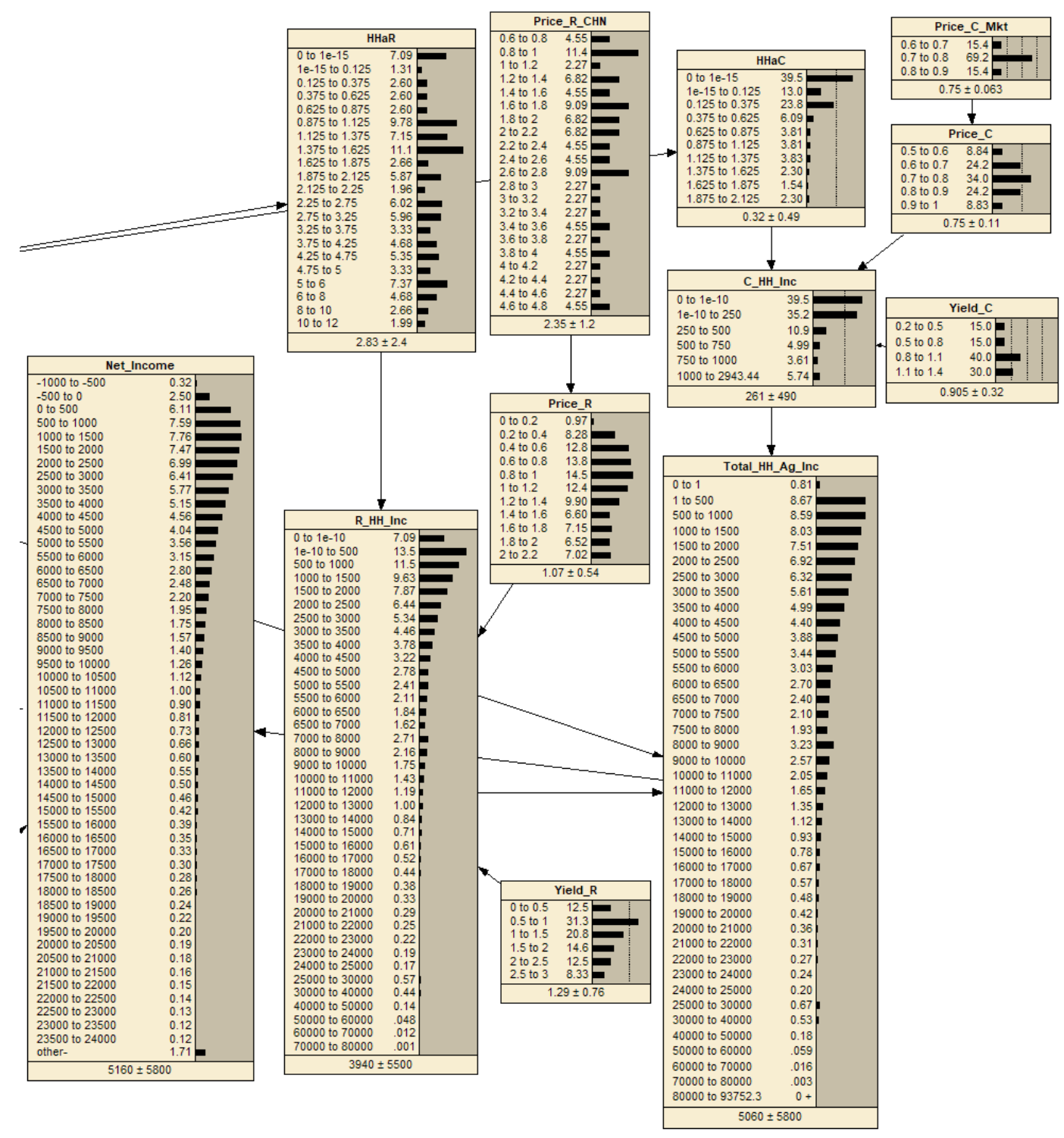

Figure A1.2 (Cont.)

Junquera, V. and Grêt-Regamey, A. Assessing livelihood vulnerability using a Bayesian network: a case study in northern Laos. 
Appendix 9/10
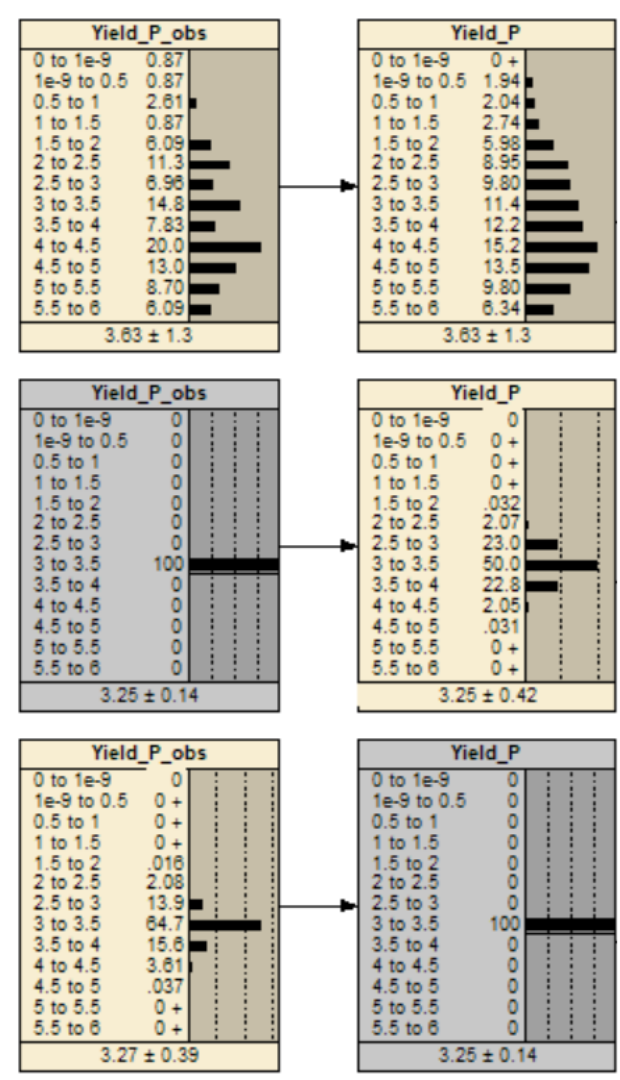

Figure A1.3: Details of forward and backward propagation of information in the BN in two selected nodes. The yellow boxes reflect the probability distribution of the node in the BN. The gray boxes reflect nodes that have been "instantiated", that is, fixed or "given evidence"; any change to the probability distribution of a node is then forward-and back-propagated across nodes in the BN. 
Appendix 10/10

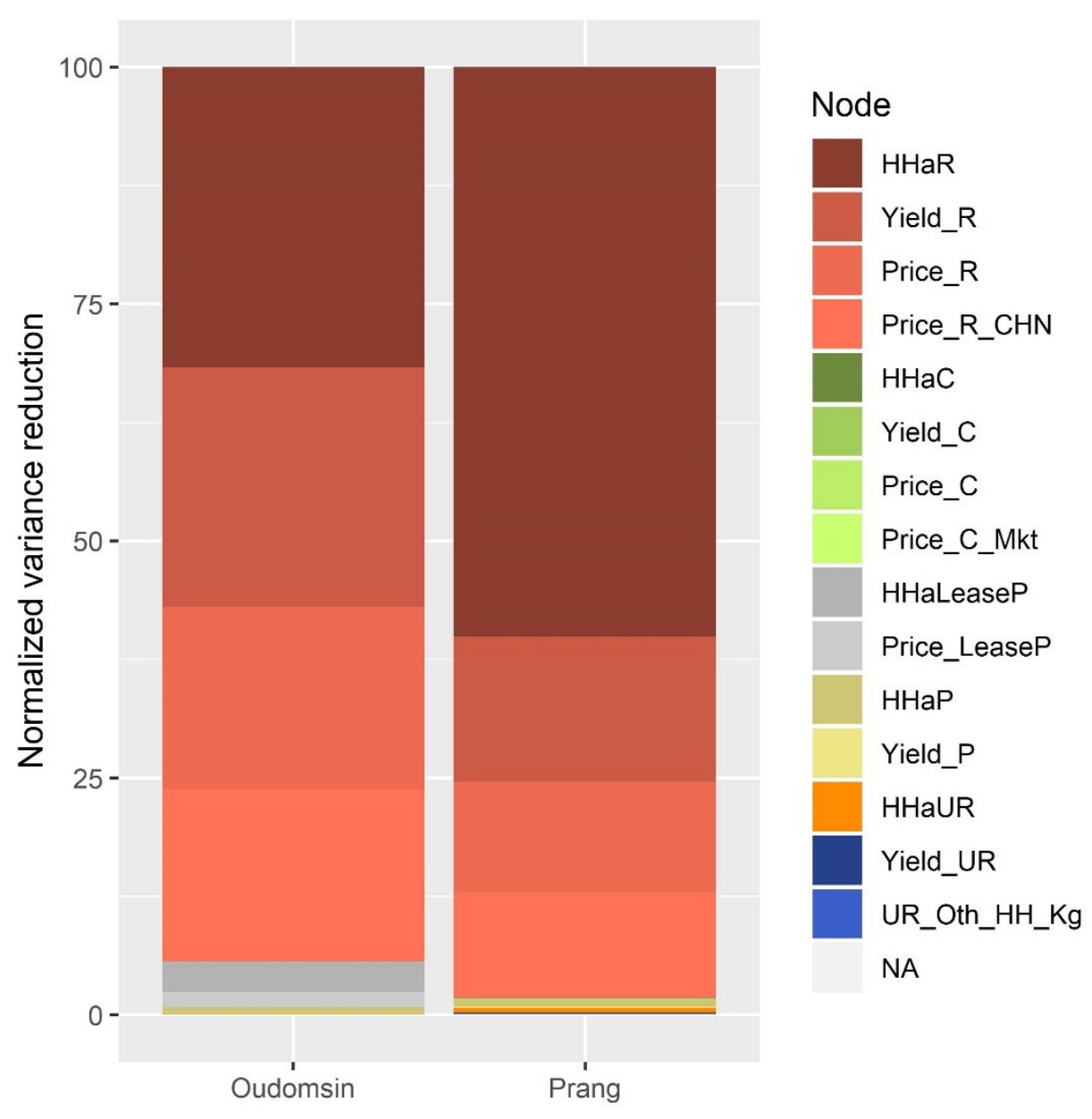

Figure A1.4: Sensitivity of net household agricultural production income to other variables (nodes) in the BN, calculated as the percent reduction in variation of the node when the value of another node is fixed. 